In cooperation with the Southern Division Naval Facilities Engineering Command

\title{
Oxidation-Reduction Processes in Ground Water at Naval Weapons Industrial Reserve Plant, Dallas, Texas
}

Water-Resources Investigations Report 03-4046

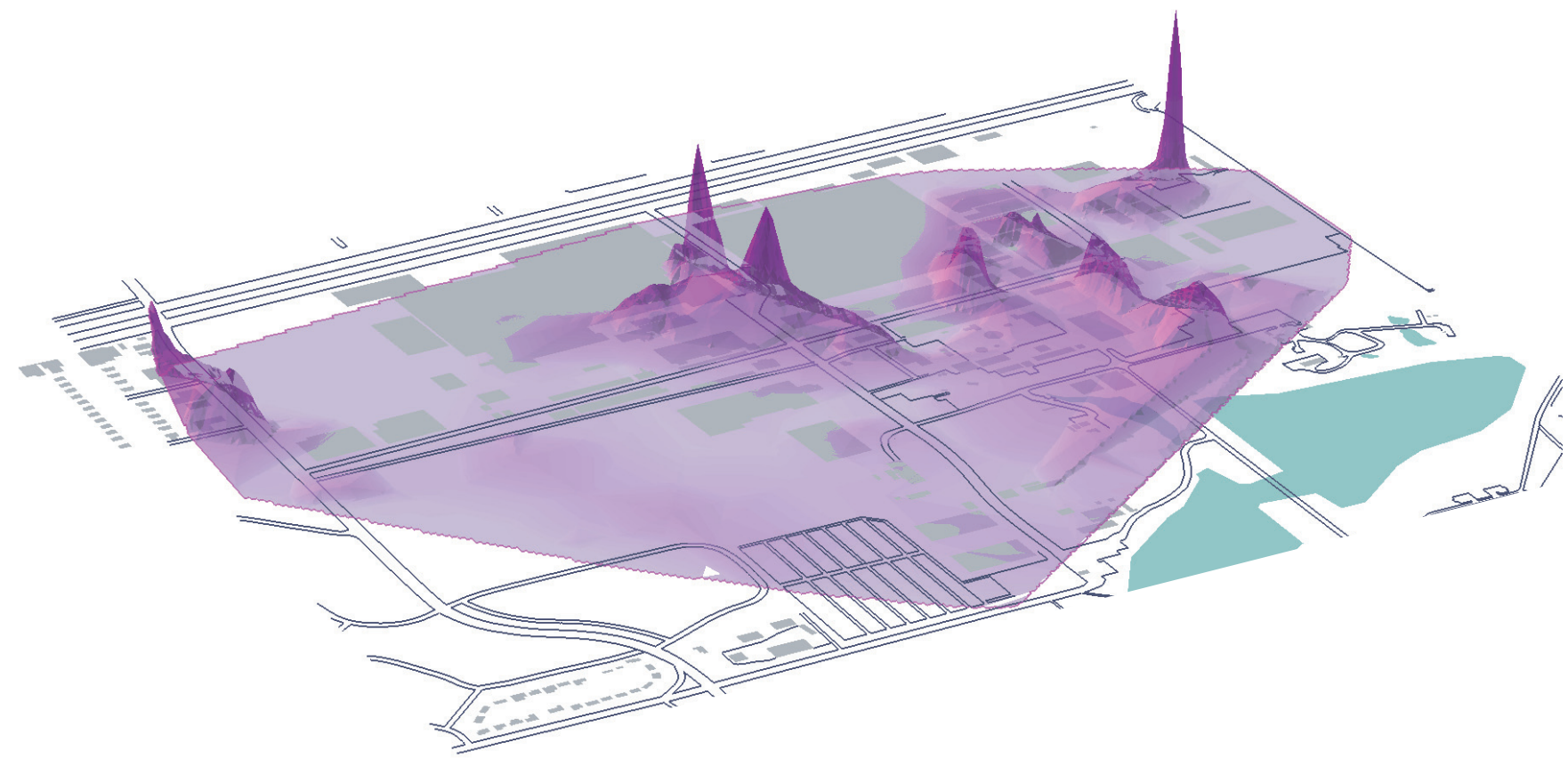

U.S. Department of the Interior U.S. Geological Survey 
U.S. Department of the Interior

U.S. Geological Survey

\section{Oxidation-Reduction Processes in Ground Water at Naval Weapons Industrial Reserve Plant, Dallas, Texas}

By S.A. Jones, Christopher L. Braun, and Roger W. Lee

U.S. GEOLOGICAL SURVEY

Water-Resources Investigations Report 03-4046

In cooperation with the Southern Division Naval Facilities Engineering Command 


\section{U.S. DEPARTMENT OF THE INTERIOR}

Gale A. Norton, Secretary

\section{U.S. GEOLOGICAL SURVEY}

Charles G. Groat, Director

Any use of trade, product, or firm names is for descriptive purposes only and does not imply endorsement by the U.S. Government.

For additional information write to

\section{District Chief}

U.S. Geological Survey

8027 Exchange Dr.

Austin, TX 78754-4733

E-mail: dc_tx@usgs.gov

Copies of this report can be purchased from

U.S. Geological Survey

Branch of Information Services

Box 25286

Denver, CO 80225-0286

E-mail: infoservices@usgs.gov 


\section{CONTENTS}

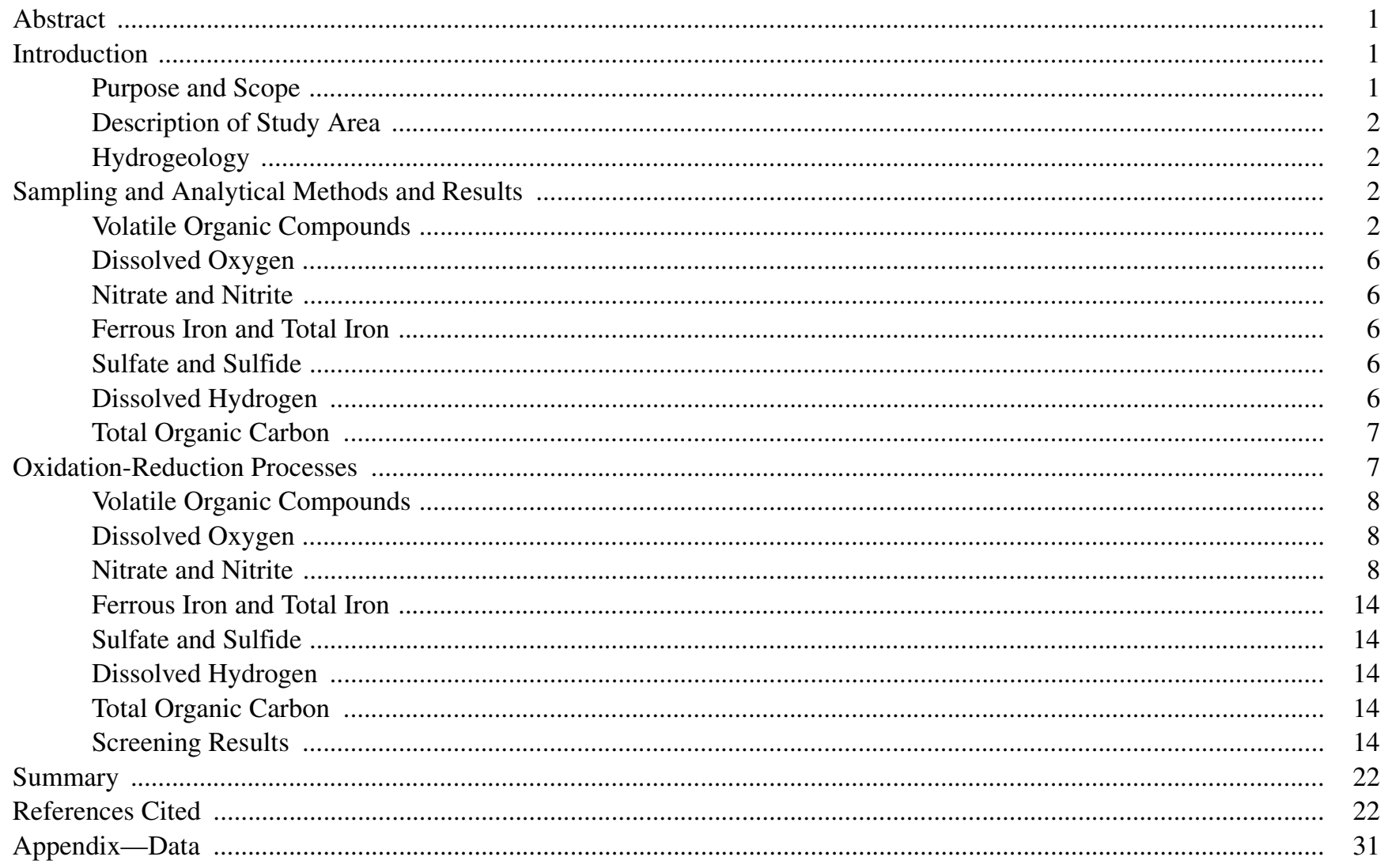

\section{FIGURES}

1. Map showing location of study area, wells sampled, and lithologic cross section $1-l^{\prime}$ at the Naval Weapons Industrial Reserve Plant, Dallas, Texas

2. Lithologic section $1-l^{\prime}$ at the Naval Weapons Industrial Reserve Plant, Dallas, Texas ......

3. Map showing water-level altitudes in shallow alluvial deposits at the Naval Weapons Industrial Reserve Plant, Dallas, Texas, March 1998

4. Graph showing dissolved hydrogen concentrations associated with oxidation-reduction processes in ground water

5-16. Maps showing:

5. Trichloroethene concentrations from wells screened in the upper or in the upper and middle parts of the shallow alluvial deposits at the Naval Weapons Industrial Reserve Plant, Dallas, Texas, September 1997

6. cis-1,2-Dichloroethene concentrations from wells screened in the upper or in the upper and middle parts of the shallow alluvial deposits at the Naval Weapons Industrial Reserve Plant, Dallas, Texas, September 1997

7. Vinyl chloride concentrations from wells screened in the upper or in the upper and middle parts of the shallow alluvial deposits at the Naval Weapons Industrial Reserve Plant, Dallas, Texas, September 1997

8. Dissolved oxygen concentrations from wells screened in the upper or in the upper and middle parts of the shallow alluvial deposits at the Naval Weapons Industrial Reserve Plant, Dallas, Texas, September 1997 
9. Dissolved oxygen concentrations from wells screened in the upper or in the upper and middle parts of the shallow alluvial deposits at the Naval Weapons Industrial Reserve Plant, Dallas, Texas, March 1998

10. Nitrite concentrations from wells screened in the upper or in the upper and middle parts of the shallow alluvial deposits at the Naval Weapons Industrial Reserve Plant, Dallas, Texas, September 1997

11. Ferrous iron concentrations from wells screened in the upper or in the upper and middle parts of the shallow alluvial deposits at the Naval Weapons Industrial Reserve Plant, Dallas, Texas, September 1997

12. Ferrous iron concentrations from wells screened in the upper or in the upper and middle parts of the shallow alluvial deposits at the Naval Weapons Industrial Reserve Plant, Dallas, Texas, March 1998

13. Sulfide concentrations from wells screened in the upper or in the upper and middle parts of the shallow alluvial deposits at the Naval Weapons Industrial Reserve Plant, Dallas, Texas, September 1997

14. Sulfide concentrations from wells screened in the upper or in the upper and middle parts of the shallow alluvial deposits at the Naval Weapons Industrial Reserve Plant, Dallas, Texas, March 1998

15. Dissolved hydrogen concentrations from wells screened in the upper or in the upper and middle parts of the shallow alluvial deposits and indicated oxidation-reduction processes at the Naval Weapons Industrial Reserve Plant, Dallas, Texas, September 1997

16. Dissolved hydrogen concentrations from wells screened in the upper or in the upper and middle parts of the shallow alluvial deposits and indicated oxidation-reduction processes at the Naval Weapons Industrial Reserve Plant, Dallas, Texas, March 1998

\section{TABLES}

1. Well information and sampling dates for wells sampled at the Naval Weapons Industrial Reserve Plant, Dallas, Texas

2. Selected constituents, methods, and procedures used to evaluate oxidation-reduction processes in ground water at the Naval Weapons Industrial Reserve Plant, Dallas, Texas

3. Chemical results for selected volatile organic compounds from wells sampled at the Naval Weapons Industrial Reserve Plant, Dallas, Texas

4. Selected field and laboratory data from wells sampled at the Naval Weapons Industrial Reserve Plant, Dallas, Texas

5. Mean first-order decay rates and computed half-lives for trichloroethene, dichloroethene, and vinyl chloride under five oxidation-reduction conditions

\section{ABBREVIATIONS AND VERTICAL DATUM}

\author{
${ }^{\circ} \mathrm{C}$, degree Celsius \\ $\mathrm{ft}$, foot \\ $\mathrm{ft} / \mathrm{ft}$, foot per foot \\ $\mathrm{ft} / \mathrm{mi}$, foot per mile \\ $\mathrm{gal} / \mathrm{min}$, gallon per minute \\ in., inch
}

\author{
$\mu \mathrm{g} / \mathrm{L}$, microgram per liter \\ $\mathrm{mg} / \mathrm{L}$, milligram per liter \\ $\mathrm{mL}$, milliliter \\ $\mathrm{mL} / \mathrm{min}$, milliliter per minute \\ $\mathrm{nm}$, nanometer \\ $\mathrm{nM}$, nanomolar
}




\title{
Oxidation-Reduction Processes in Ground Water at Naval Weapons Industrial Reserve Plant, Dallas, Texas
}

\author{
By S.A. Jones, Christopher L. Braun, and Roger W. Lee
}

\section{Abstract}

Concentrations of trichloroethene in ground water at the Naval Weapons Industrial Reserve Plant in Dallas, Texas, indicate three source areas of chlorinated solvents-building 1, building 6 , and an off-site source west of the facility. The presence of daughter products of reductive dechlorination of trichloroethene, which were not used at the facility, south and southwest of the source areas are evidence that reductive dechlorination is occurring. In places south of the source areas, dissolved oxygen concentrations indicated that reduction of oxygen could be the dominant process, particularly south of building 6 ; but elevated dissolved oxygen concentrations south of building 6 might be caused by a leaking water or sewer pipe. The nitrite data indicate that denitrification is occurring in places; however, dissolved hydrogen concentrations indicate that iron reduction is the dominant process south of building 6 . The distributions of ferrous iron indicate that iron reduction is occurring in places south-southwest of buildings 6 and 1; dissolved hydrogen concentrations generally support the interpretation that iron reduction is the dominant process in those places. The generally low concentrations of sulfide indicate that sulfate reduction is not a key process in most sampled areas, an interpretation that is supported by dissolved hydrogen concentrations. Ferrous iron and dissolved hydrogen concentrations indicate that ferric iron reduction is the primary oxidationreduction process. Application of mean first-order decay rates in iron-reducing conditions for trichloroethene, dichloroethene, and vinyl chloride yielded half-lives for those solvents of 231, 347, and 2.67 days, respectively. Decay rates, and thus half-lives, at the facility are expected to be similar to those computed. A weighted scoring method to indicate sites where reductive dechlorination might be likely to occur indicated strong evidence for anaerobic biodegradation of chlorinated solvents at six sites. In general, scores were highest for samples collected on the northeast side of the facility.

\section{INTRODUCTION}

The Naval Weapons Industrial Reserve Plant (NWIRP) in Dallas, Tex., has been in operation since 1941. The 314-acre NWIRP facility, which currently (2002) is operated by Vought Aircraft Industries Inc., manufactures military and commercial aircraft and aircraft components. Manufacturing processes associated with the facility's operation include metal machining and treating; fabrication, painting, and stripping of aircraft or aircraft parts; and aircraft renovation. These processes use petroleum products and solvents and create wastes that include oils and fuels, chlorinated solvents, construction debris, and metals. The chlorinated ethenes trichloroethene (TCE), 1,2-cis-dichloroethene (cis-DCE), 1,2-trans-dichloroethene (trans-DCE), and vinyl chloride (VC) as well as chlorinated ethanes have been detected at various locations in the shallow alluvial deposits at the site (EnSafe/Allen \& Hoshall, 1994, 1996). Multiple ground-water contamination plumes exist in the shallow alluvial deposits at the site because of several source areas (EnSafe/Allen \& Hoshall, 1996). Presently, the facility is operating under a Resource Conservation and Recovery Act Part B permit.

\section{Purpose and Scope}

This report describes the oxidation-reduction (redox) processes in ground water at NWIRP on the basis of data collected and analyzed by the U.S. Geological Survey (USGS) and private companies. The USGS 
collected ground-water samples from 51 wells in September 1997 and from 57 wells in March 1998 (table 1, at end of report). The USGS analyzed the September 1997 samples in the field for specific conductance, $\mathrm{pH}$, temperature, dissolved oxygen (DO), ferrous iron, total iron, sulfide, carbon dioxide, methane, and hydrogen; the March 1998 samples were analyzed in the field for specific conductance, $\mathrm{pH}$, temperature, bicarbonate alkalinity, and selected volatile organic compounds (VOCs). The USGS sent September 1997 samples to Quanterra Laboratories for analysis of bicarbonate alkalinity; sulfate; chloride; fluoride; silica; nitrate, nitrate plus nitrite, and ammonia nitrogen; orthophosphate phosphorus; boron; and total organic carbon (TOC). EnSafe/Allen \& Hoshall (hereinafter, EnSafe), a consultant to the Navy, collected groundwater samples from about 150 wells and had them analyzed by a contract laboratory for selected VOCs and metals in September 1997.

\section{Description of Study Area}

The study area is in the southwestern corner of the city of Dallas (fig. 1). NWIRP is located north of Cottonwood Bay, which is a part of Mountain Creek Lake. The climate in north-central Texas is characterized by long, hot summers and short, mild winters. The average annual precipitation in north-central Texas is 32 in., with most of the precipitation occurring during spring and fall. Land-surface altitudes at NWIRP range from about 500 to $460 \mathrm{ft}$ above sea level west to east and north to south (fig. 1). Stormwater runoff drains into a manmade channel of Mountain Creek Lake locally referred to as Cottonwood Bay.

\section{Hydrogeology}

NWIRP is located on shallow alluvial deposits about 40 to $80 \mathrm{ft}$ above the present-day flood plain of the West Fork Trinity River. The alluvial deposits range from about 10 to $75 \mathrm{ft}$ thick and overlie the Cretaceous-age Eagle Ford Shale (EnSafe/Allen \& Hoshall, 1994). A previous study used borehole geophysical logging and cone penetrometer data to map the relative permeability of the shallow alluvial deposits at the NWIRP site (Anaya and others, 2000; Braun and others, 2000). In that study, the shallow alluvial deposits were divided into upper, middle, and lower parts of roughly equal thickness. A series of intersecting sections was developed (Anaya and others, 2000, pls. 1-3), which indicates that the shallow alluvial deposits occur as lenticular, interfingering beds of sand, silt, and clay atop the shale bedrock. The relative permeability of the beds is gradational and depends on the amounts of sand (most permeable), silt, and clay (least permeable) present (fig. 2). The shallow alluvial deposits have been replaced by permeable fill material in places.

Ground water generally moves downgradient from a recharge area in the northwestern part of the study area through the shallow alluvial deposits underlying NWIRP toward the principal discharge area to the southeast, Cottonwood Bay (fig. 3). Lateral flow gradients steepen from about $25 \mathrm{ft} / \mathrm{mi}$ in the north to about $75 \mathrm{ft} / \mathrm{mi}$ in the south. Downward vertical gradients (as much as $0.5 \mathrm{ft} / \mathrm{ft}$ under natural conditions) indicate that some water migrates between upper and lower parts of the shallow alluvial deposits. Downward migration is greatest in the northern part of the study area. Upward gradients near the east lagoon, west lagoon, and along the northern shore of Cottonwood Bay (fig. 3) indicate diffuse ground-water discharge to these topographically low areas (Barker and Braun, 2000). Specific-capacity tests at more than 20 wells produced 1.5 to $2.0 \mathrm{gal} / \mathrm{min}$ of sustained flow from each well (EnSafe/Allen \& Hoshall, 1994). About 76 percent of NWIRP ground cover is impervious; most of the pervious (grassy) areas are near the south end of the facility adjacent to Cottonwood Bay (Barker and Braun, 2000).

\section{SAMPLING AND ANALYTICAL METHODS AND RESULTS}

Unfiltered ground-water samples were collected from wells using a peristaltic pump. Wells were pumped for at least 30 minutes before sampling. Constituents listed in table 2 (at end of report) were analyzed in the field or in the laboratory as indicated. The appendix lists selected additional data collected at NWIRP.

Decontamination procedures consisted of equipment cleaning and rinsing between wells using deionized water, methanol (as needed), and a dilute detergent solution (as needed). Equipment cleaned included glass bubblers for headspace analyses, monitoring probes, and glassware used with the HACH colorimeters. New Teflon and Tygon tubing was used for each well.

\section{Volatile Organic Compounds}

VOC samples were collected by EnSafe in September 1997 and analyzed by a contract laboratory using the U.S. Environmental Protection Agency (1999) method 8260. The USGS collected samples and 


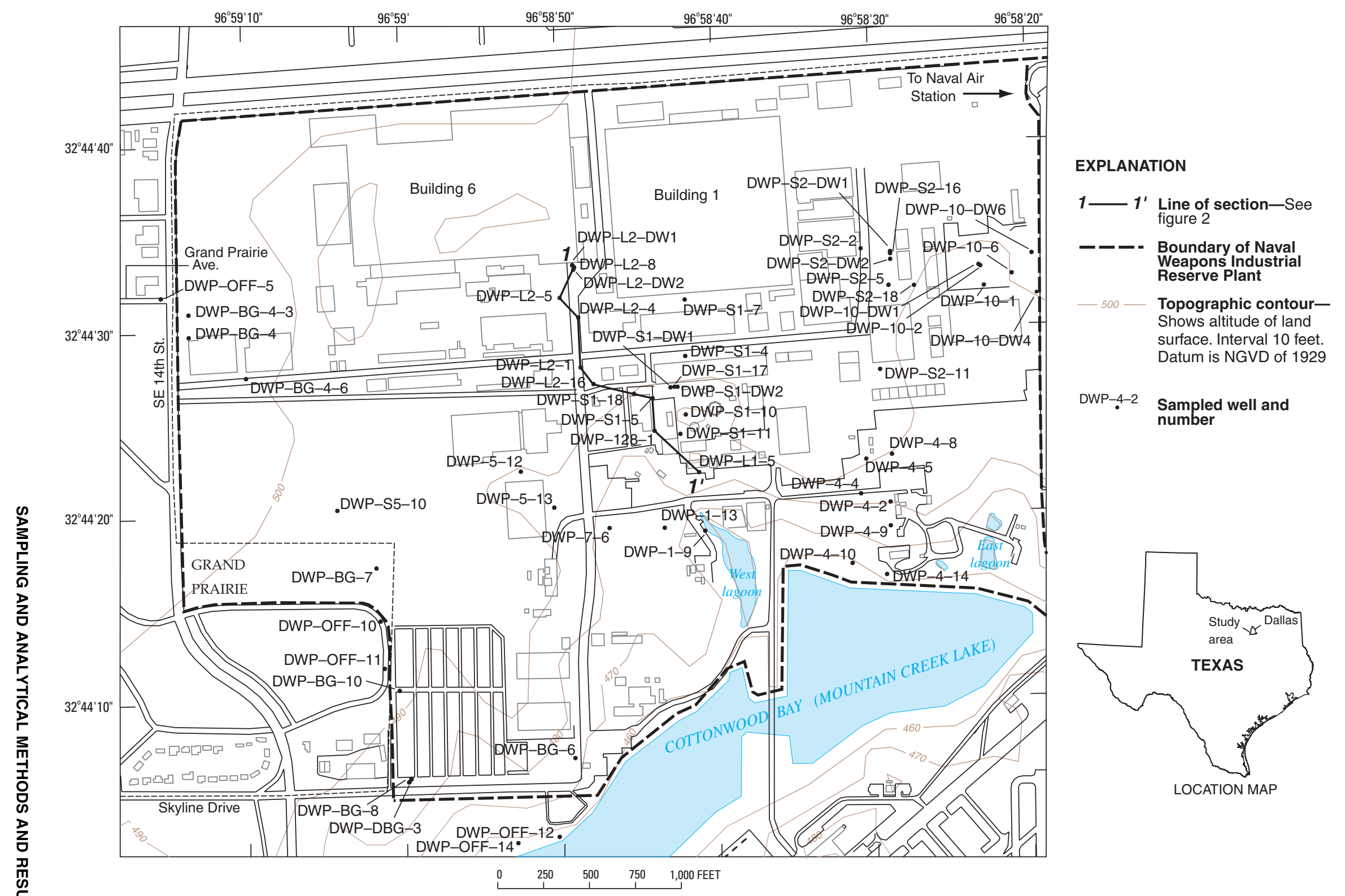

Figure 1. Location of study area, wells sampled, and lithologic cross section 1-1'at the Naval Weapons Industrial Reserve Plant, Dallas, Texas. 


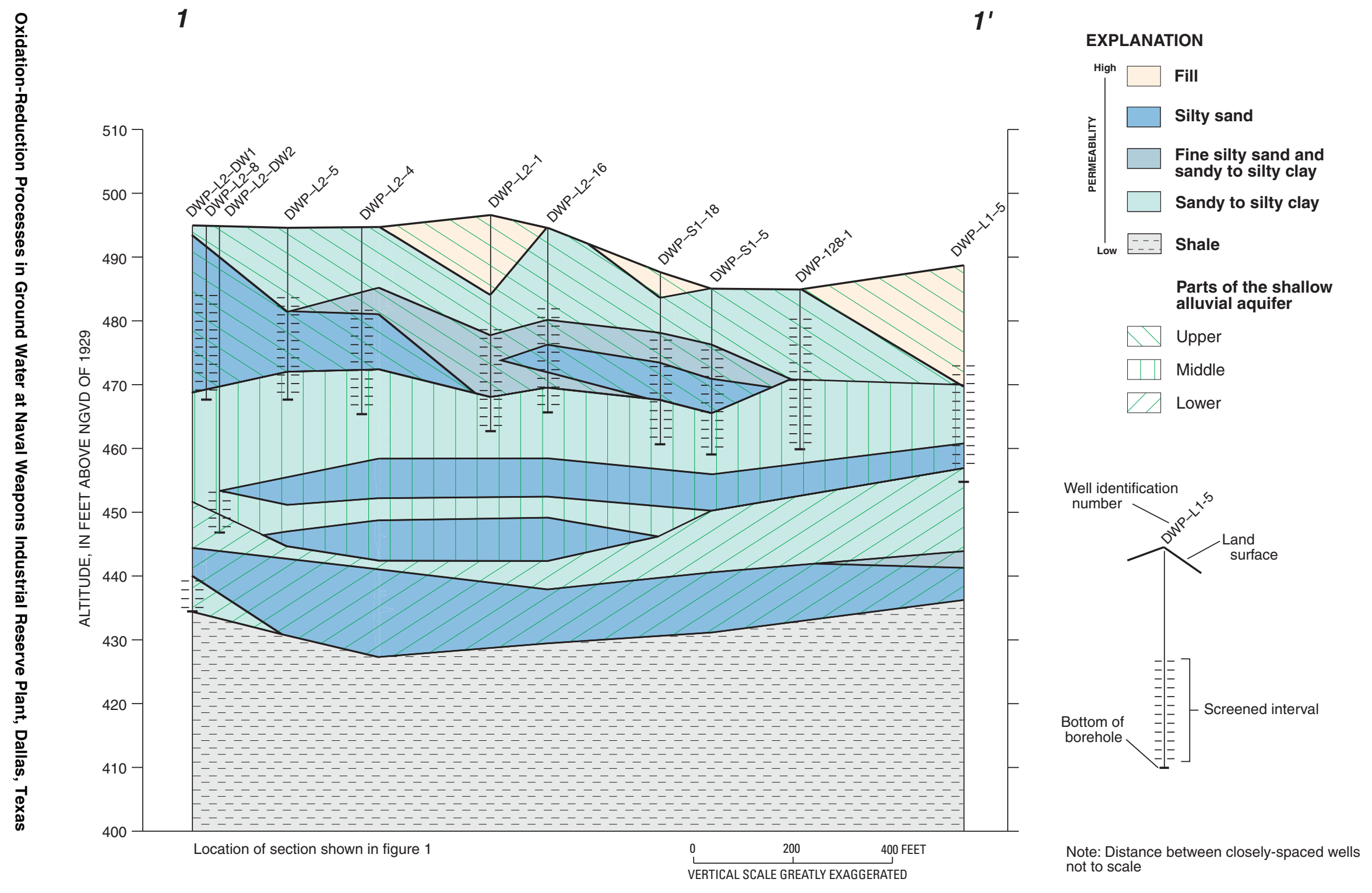

Figure 2. Lithologic section $1-1$ ' at the Naval Weapons Industrial Reserve Plant, Dallas, Texas (modified from Anaya and others, 2000; Braun and others, 2000). 


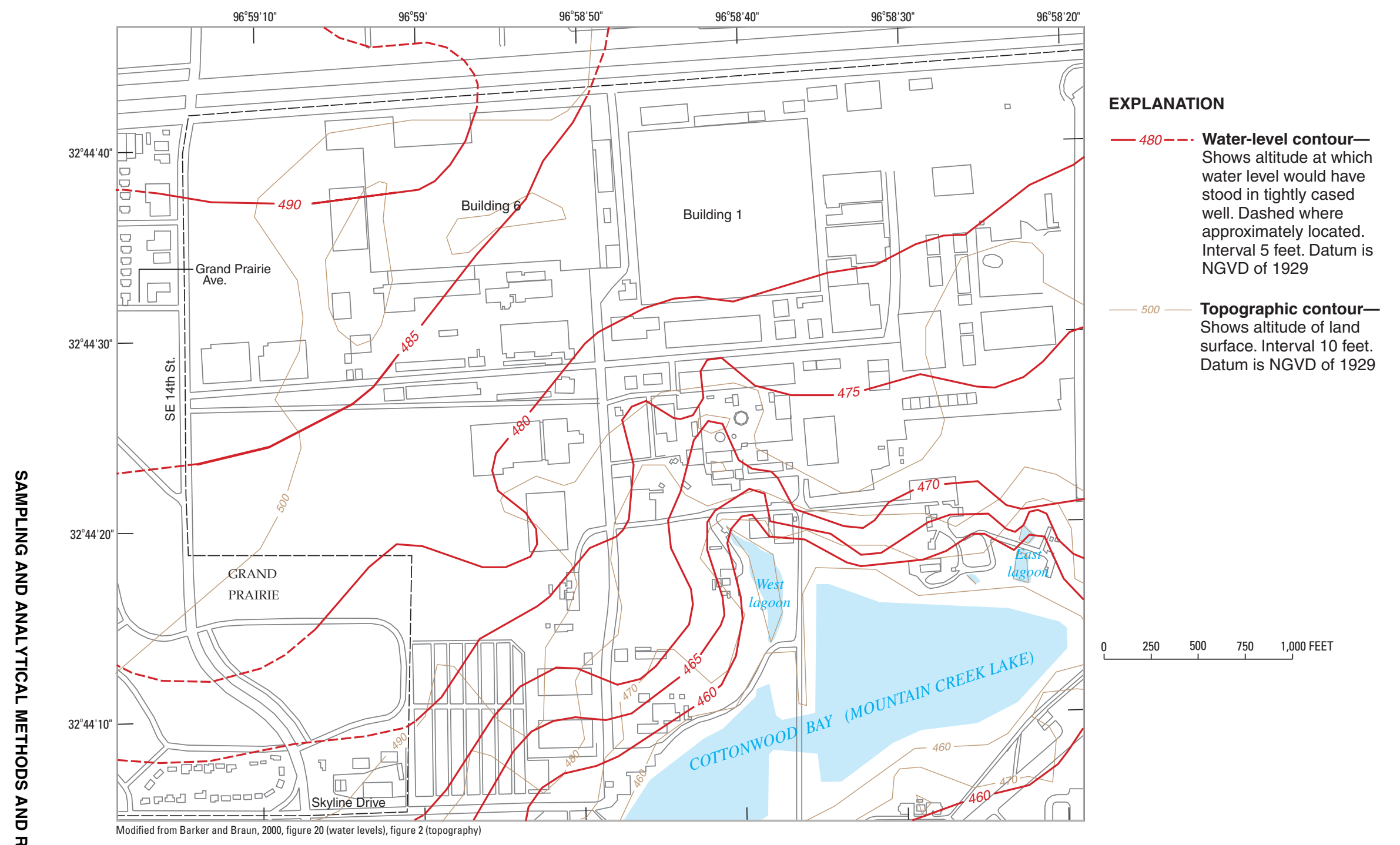

Figure 3. Water-level altitudes in shallow alluvial deposits at the Naval Weapons Industrial Reserve Plant, Dallas, Texas, March 1998. 
analyzed them with a field gas chromatograph (GC) in March 1998. The field GC results are considered semiquantitative but compare relatively well with the laboratory data. Samples analyzed in the field were collected in a $40-\mathrm{mL}$ vial. At each well, $20 \mathrm{~mL}$ of sample was collected in the vial. The vial was placed in a water bath and brought to $30^{\circ} \mathrm{C}$, the vial was shaken vigorously, and a quantity of headspace was removed with a gastight syringe and injected into a Photovac 10S50 GC calibrated for TCE, cis-DCE, trans-DCE, and VC. Results of both laboratory and field GC analyses are listed in table 3 (at end of report).

\section{Dissolved Oxygen}

The concentration of DO was measured in the field using the indigo carmine method (Gilbert and others, 1982). Ground water was pumped through Teflon tubing (having a low oxygen-diffusion coefficient) into a sampling cell. An ampoule was placed into the overflowing sample cell, and the tip was broken to draw a fixed size of sample into the ampoule. The tip was covered to ensure against atmospheric contamination of the sample. The ampoule was inverted carefully several times to mix the colordeveloping reagents with the sample and allowed to react for 2 minutes. The ampoule then was placed in a CHEMetrics VVR photometer, and the DO concentration was recorded. The method detection limit for DO was $0.05 \mathrm{mg} / \mathrm{L}$. Results of DO analyses are listed in table 4 (at end of report).

\section{Nitrate and Nitrite}

Nitrate as nitrogen and nitrate plus nitrite as nitrogen samples were collected by the USGS in September 1997 and analyzed by Quanterra Laboratories using methods 300.0 and 353.2 (U.S. Environmental Protection Agency, 1993 and 1983, respectively). Nitrite concentrations are listed in table 4 . Nitrate and nitrate plus nitrite concentrations are listed in the appendix.

\section{Ferrous Iron and Total Iron}

The concentration of ferrous iron was measured using the HACH phenanthroline powder pillow method (255), and the concentration of total iron was measured using the HACH FerroVer colorimetric method (265) (HACH Co., 1989). For ferrous and total iron, $25 \mathrm{~mL}$ of ground water was poured into each of four colorimetric vials. The ferrous and total iron reagents, respectively, were then added to the first and second sample vials; the vials were filled with sample and allowed to react for 3 minutes. The third and fourth sample vials (the blanks) were placed in a DR2000 spectrophotometer, and the zero concentration was set at a 510-nm wavelength. The blank vials were removed, and each ground-watersample vial was placed in the spectrophotometer; after 3 minutes, concentrations of ferrous and total iron, in milligrams per liter, were recorded. The lower and upper method detection limits for ferrous and total iron using the methods and instrumentation listed above were 0.01 and $3 \mathrm{mg} / \mathrm{L}$, respectively. If a sample concentration was greater than $3 \mathrm{mg} / \mathrm{L}$, a 50-percent dilution of the sample with deionized (DI) water was used, and the sample was re-analyzed. Several of the ferrous iron samples collected in September 1997 became cloudy during color development, causing incorrect readings on the spectrophotometer. The concentrations reported for cloudy ferrous samples in table 4 are qualified.

\section{Sulfate and Sulfide}

Sulfate samples were collected by the USGS in September 1997 and analyzed by Quanterra Laboratories (appendix). The concentration of sulfide was measured using the $\mathrm{HACH}$ methylene blue colorimetric method (690) (HACH Co., 1989). For sulfide a $25 \mathrm{~mL}$ sample of ground water was collected into a sample cell, and a second sample cell was filled with DI water. One $\mathrm{mL}$ of sulfide reagent 1 was added to each sample cell and swirled to mix. After mixing, $1 \mathrm{~mL}$ of sulfide reagent 2 was immediately added to each vial and swirled to mix. The methylene blue color was allowed to develop for 5 minutes. After 5 minutes, the blank sample was placed into the DR2000 spectrophotometer, and the zero concentration was set at a $665-\mathrm{nm}$ wavelength. The blank sample cell was removed, the sample cell containing the ground-water sample was placed in the colorimeter, and the concentration of sulfide, in milligrams per liter, was recorded. The lower and upper method detection limits for sulfide using the method and instrumentation listed above were 0.001 and $0.6 \mathrm{mg} / \mathrm{L}$, respectively. Sulfide concentrations are listed in table 4.

\section{Dissolved Hydrogen}

The concentration of dissolved hydrogen was measured using the "bubble strip" method (Chapelle, 1996) in which ground water was pumped through a glass bubbler fitted with a septum. Once flow was 
established at about $500 \mathrm{~mL} / \mathrm{min}$ and the bubbler was filled and free of gas bubbles, $20 \mathrm{~mL}$ of hydrogen-free helium was injected. The induced headspace was allowed to equilibrate with the flowing ground water for about 30 minutes. After 30 minutes, $10 \mathrm{~mL}$ of the headspace gas was withdrawn using a 10 -mL gas-tight syringe with valve; after 5 minutes, a second $10-\mathrm{mL}$ sample of the headspace gas was withdrawn into a second syringe. Both samples were analyzed for hydrogen using a reducing gas detector chromatograph (Trace Analytical, 1997) calibrated with standard gases. Dissolved hydrogen concentrations listed in table 4 are an average of the two measurements.

\section{Total Organic Carbon}

TOC samples were collected by the USGS in September 1997 and analyzed by Quanterra Laboratories using method 9060 (U.S. Environmental Protection Agency, 1999). TOC concentrations are listed in the appendix.

\section{OXIDATION-REDUCTION PROCESSES}

The most common redox processes in ground water are the reduction of oxygen, nitrate (denitrification), ferric iron, sulfate, and carbon dioxide (methanogenesis). The reduced chemical species produced during redox reactions are used in biological processes that facilitate reductive dechlorination of chlorinated solvents. The efficiency of the reductive dechlorination process varies depending on redox conditions. Dechlorination of the more highly chlorinated solvents (tetrachloroethene [PCE], TCE, and DCE) can occur in mildly reducing environments, such as those associated with ferric iron reduction, but dechlorination is more efficient in sulfate-reducing or methanogenic conditions (Chapelle, 1996; Suarez and Rifai, 1999). VC typically requires a more strongly reducing environment such as methanogenesis to degrade but also will degrade under iron-reducing conditions and under aerobic conditions (Bradley and Chapelle, 1998). Table 5 (at end of report) lists mean first-order decay rates for TCE, DCE, and VC under five redox conditions and the computed half-lives associated with the respective decay rates. In general, the larger the first-order decay rate, the more efficient the reductive dechlorination process.

Hydrogen is produced during anaerobic microbial metabolism. It is then used by respirative microorganisms that most commonly use ferric iron, sulfate, or carbon dioxide as electron acceptors. Dissolved hydrogen concentrations can be used to identify which redox process is dominant at a particular location (fig. 4). Of the reducing environments noted above, methanogenesis consumes the least hydrogen. Hydrogen concentrations in ground water are expected to be greater than $5.0 \mathrm{nM}$ under methanogenic conditions. If sulfate reduction is the dominant redox process, hydrogen concentrations will range from 1.0 to $4.0 \mathrm{nM}$. If ferric iron reduction is the dominant redox process, hydrogen concentrations will range from 0.2 to $0.8 \mathrm{nM}$. If denitrification is the dominant redox process, hydrogen concentrations will be less than $0.1 \mathrm{nM}$ (Chapelle, 1996).

In addition to dissolved hydrogen concentrations, concentrations of the reduced species nitrite, ferrous iron, sulfide, and methane are useful for identifying redox processes. In some cases, determination of dissolved hydrogen concentrations might not be necessary; but when concentrations of the reduced species produce conflicting information, hydrogen concentrations are critical. For example, ferrous iron, sulfide, and methane can be transported by ground-water flow in the subsurface. The constituents could be produced upgradient and transported to the well where the measurement is made. To determine which redox process is dominant at the well where the measurement is made, dissolved hydrogen concentrations are needed.

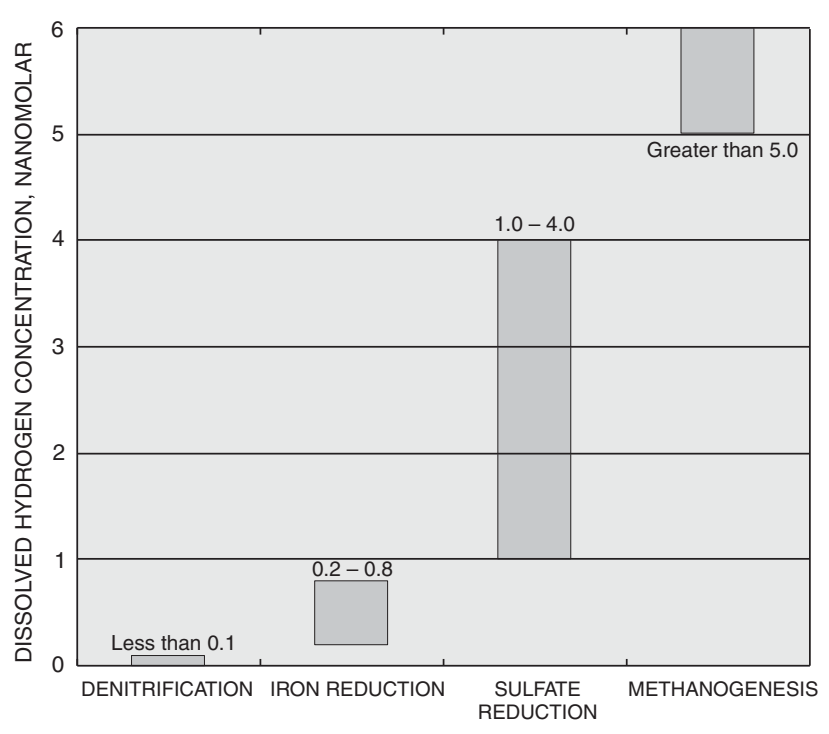

Figure 4. Dissolved hydrogen concentrations associated with oxidation-reduction processes in ground water (modified from Chapelle, 1996). 


\section{Volatile Organic Compounds}

The concentrations of chlorinated solvents at NWIRP are controlled partially by reductive dechlorination, which in turn is controlled by redox processes in ground water. Under anaerobic conditions, reductive dechlorination of TCE proceeds as follows:

$$
\mathrm{TCE}=>\text { cis-DCE }+\mathrm{Cl}=>\mathrm{VC}+2 \mathrm{Cl}=>\text { ethene }+3 \mathrm{Cl} \text {. }
$$

The presence of cis-DCE and VC usually indicates that reductive dechlorination of TCE is occurring. Normally cis-DCE is not used as a primary solvent. It is more commonly a product of the degradation of a more highly chlorinated compound. Neither cis-DCE nor VC was used at NWIRP (EnSafe/Allen \& Hoshall, 1996). Therefore, the presence of these daughter products indicates that TCE is degrading. The presence of VC indicates that cis-DCE is degrading; but it also indicates that complete reductive dechlorination (eq. 1) might not be occurring in all areas of the facility. Figures 5, 6, and 7 show the distributions of TCE, cis-DCE, and VC, respectively, in shallow ground water at NWIRP. These maps were created using data collected by EnSafe in September 1997 from about 150 wells. Most of the wells were screened in the upper part of the shallow alluvial deposits only; some were screened in the upper and middle parts; and a few were screened in the middle and (or) lower part. The high dilution factors used during laboratory analyses might have masked smaller concentrations of VC in some samples. Concentrations less than the method detection limit were not used in the generation of the concentration maps.

The three primary source areas for chlorinated solvents in ground water at NWIRP are building 1, building 6 , and an off-site source west of the facility. Concentrations of chlorinated solvents are highest near these areas (figs. 5, 6, and 7). Each of three plumes (one from each source area) has distinctly different chemistry with respect to chlorinated solvents. The plume originating from the building 1 area contains chlorinated ethenes and chlorinated ethanes including trichloroethane and 1,1-dichloroethane (appendix). The plume originating from the building 6 area primarily is composed of chlorinated ethenes. The source area of building 6 generally has a larger TCE/cis-DCE ratio than other areas of NWIRP. Larger ratios generally indicate that reductive dechlorination is less efficient than in areas where the ratio is smaller. The plume that originates off-site is the only plume in which PCE concentrations are greater than $10 \mu \mathrm{g} / \mathrm{L}$. Wells DWP-OFF-5,
DWP-BG-4, and DWP-BG-4-3 had PCE concentrations of 170,98 , and $43 \mu \mathrm{g} / \mathrm{L}$, respectively (appendix).

\section{Dissolved Oxygen}

DO concentrations greater than about $0.50 \mathrm{mg} / \mathrm{L}$ indicate that oxygen reduction is the dominant microbial process (U.S. Environmental Protection Agency, 1998). Oxygen reduction occurs as follows:

$$
\mathrm{CH}_{2} \mathrm{O}+\mathrm{O}_{2}=>\mathrm{CO}_{2}+\mathrm{H}_{2} \mathrm{O} \text {. }
$$

Ground water is unconfined in shallow alluvial deposits at NWIRP, and both anaerobic (DO less than $0.50 \mathrm{mg} / \mathrm{L}$ ) and aerobic (DO greater than $0.50 \mathrm{mg} / \mathrm{L}$ ) (U.S. Environmental Protection Agency, 1998) groundwater conditions were observed at various locations. DO concentrations tended to be less than $1.00 \mathrm{mg} / \mathrm{L}$ but were as high as $2.29 \mathrm{mg} / \mathrm{L}$ (table 4 ); the mean concentration was $0.55 \mathrm{mg} / \mathrm{L}$ for samples collected in September 1997 and $0.35 \mathrm{mg} / \mathrm{L}$ for samples collected in March 1998. Several wells sampled south of building 6, a primary source area, had DO concentrations greater than $1.00 \mathrm{mg} / \mathrm{L}$ during both sampling events (figs. 8, 9). These concentrations are higher than would be expected near the source of a plume. One possible explanation is a leaking underground water or sewer pipe. Barker and Braun (2000) indicated that near the area where DO concentrations are larger, recharge was added to a ground-water-flow model of NWIRP to simulate an additional source of water other than infiltration of precipitation. The authors believe the observed DO concentrations more likely are related to an inflow of water rather than oxygen reduction. In general, the distribution of DO was similar for September 1997 and March 1998.

\section{Nitrate and Nitrite}

Nitrate is reduced to nitrite as follows:

$$
\mathrm{CH}_{2} \mathrm{O}+2 \mathrm{NO}_{3}^{-}=>2 \mathrm{NO}_{2}^{-}+\mathrm{CO}_{2}+\mathrm{H}_{2} \mathrm{O} \text {. }
$$

Because of this process, an increase in nitrite would be expected where nitrate reduction is occurring. The mean concentration of nitrite in those samples containing nitrite collected in September 1997 was $0.36 \mathrm{mg} / \mathrm{L}$. The nitrite data indicate that nitrate reduction is occurring in places. Nitrite concentrations equal to or greater than $0.5 \mathrm{mg} / \mathrm{L}$ were detected in six wells (screened in the upper or in the upper and middle parts of the shallow alluvial deposits) - DWP-4-2, DWP-4-4, DWP-4-9, DWP-L2-1, DWP-L2-16, and 


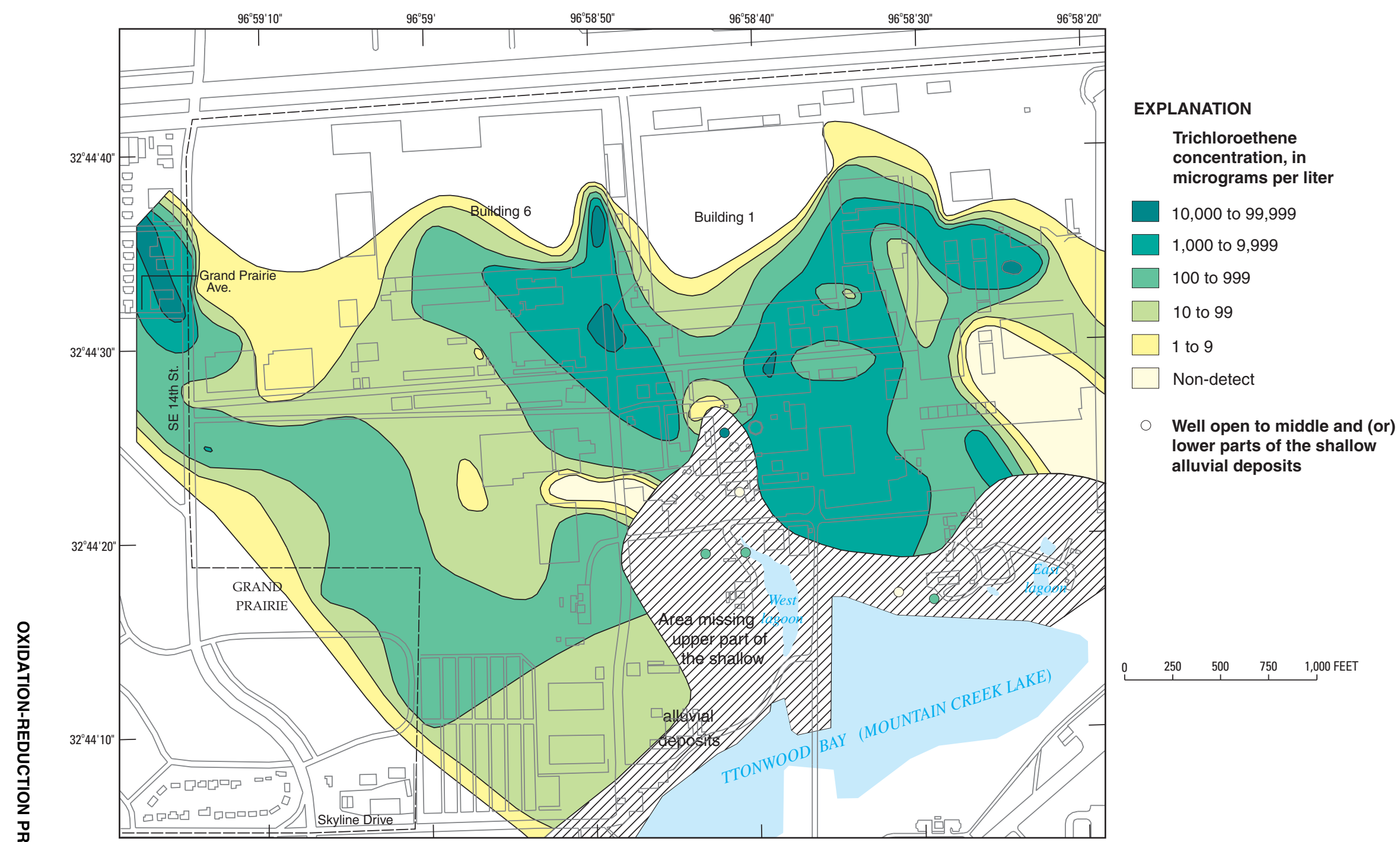

Figure 5. Trichloroethene concentrations from wells screened in the upper or in the upper and middle parts of the shallow alluvial deposits at the Naval Weapons Industrial Reserve Plant, Dallas, Texas, September 1997. (Concentration datapoints provided by EnSafe/Allen \& Hoshall.) 


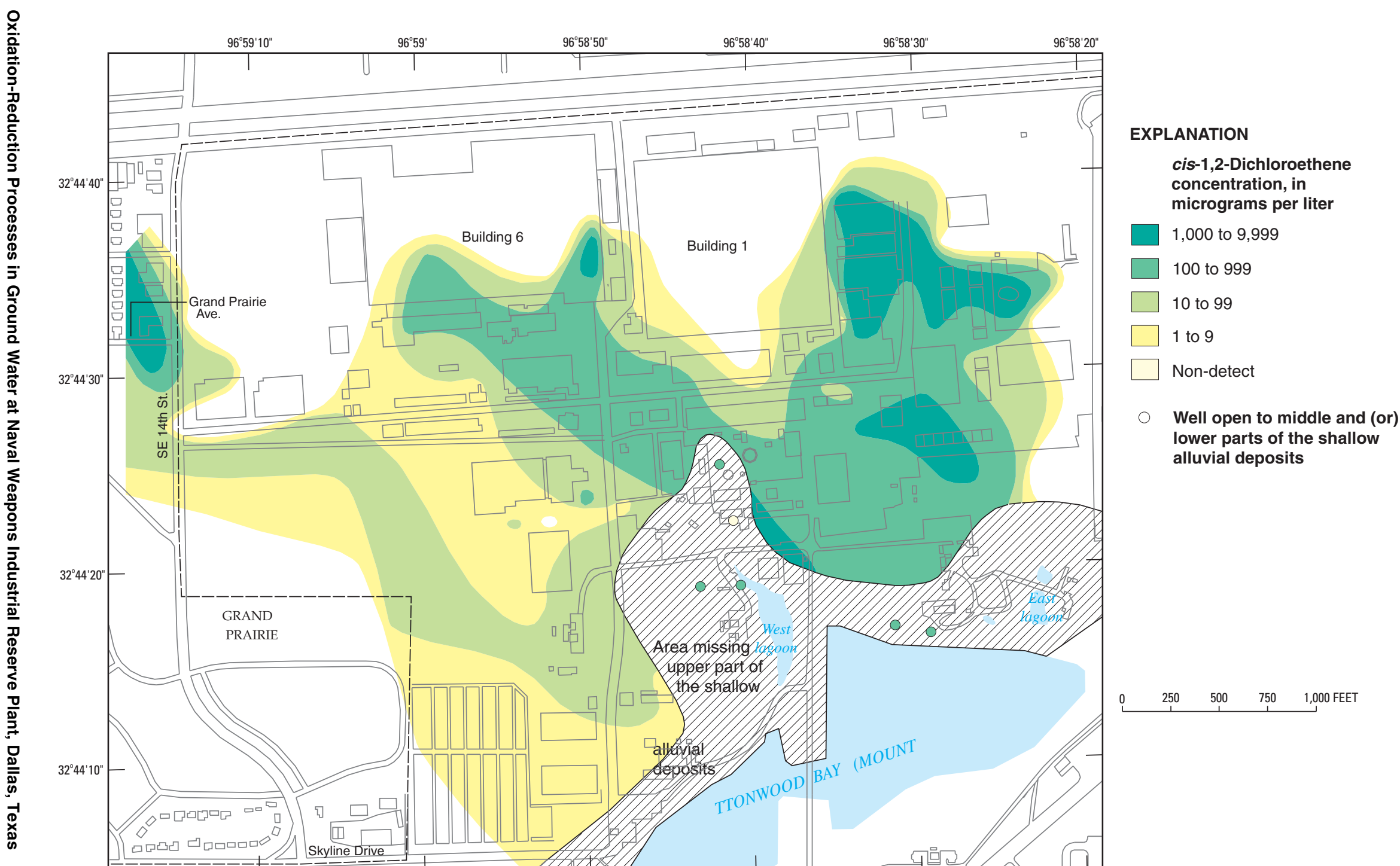

Figure 6. cis-1,2-Dichloroethene concentrations from wells screened in the upper or in the upper and middle parts of the shallow alluvial deposits at the Naval Weapons Industrial Reserve Plant, Dallas, Texas, September 1997. (Concentration datapoints provided by EnSafe/Allen \& Hoshall.) 


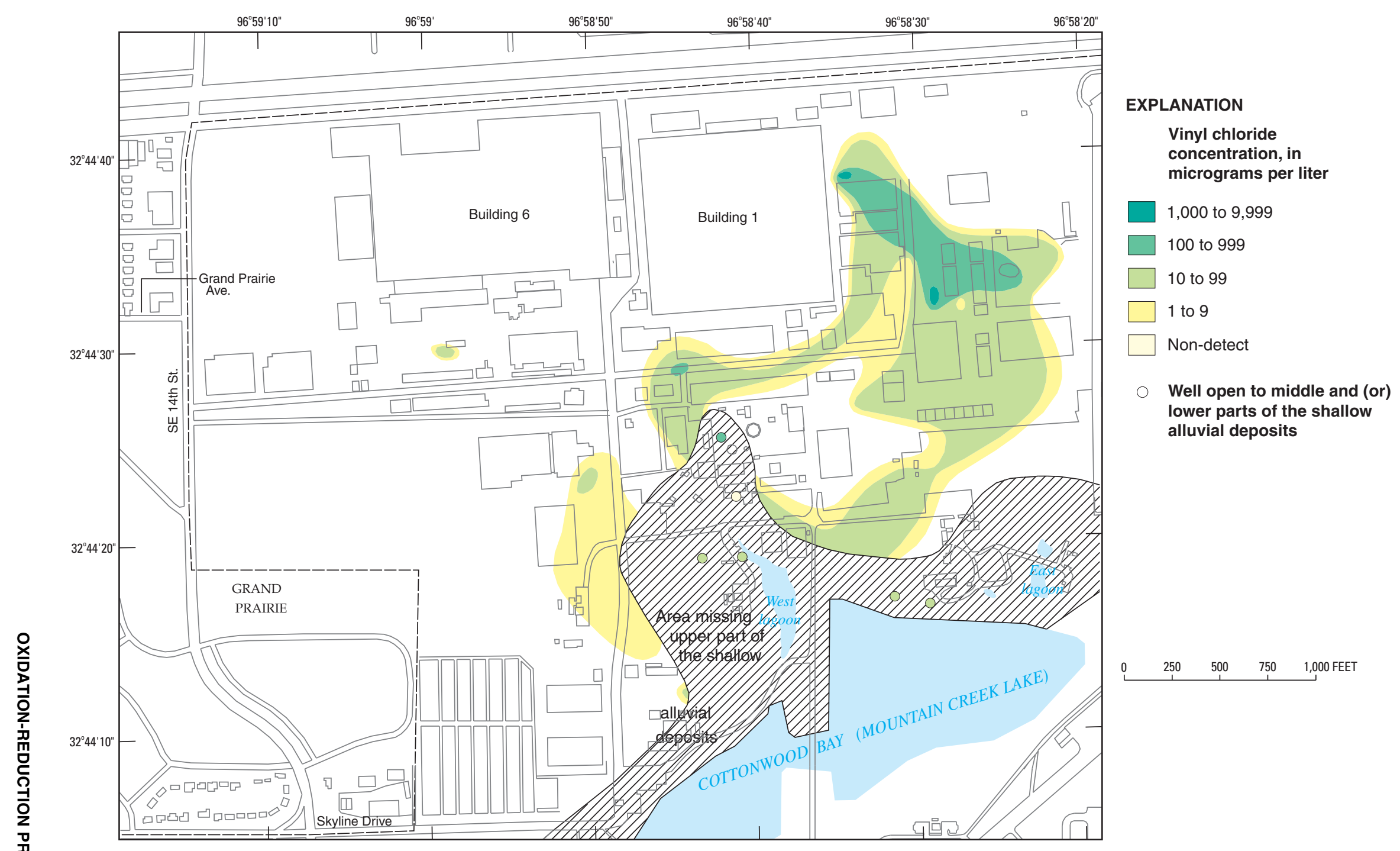

Figure 7. Vinyl chloride concentrations from wells screened in the upper or in the upper and middle parts of the shallow alluvial deposits at the 


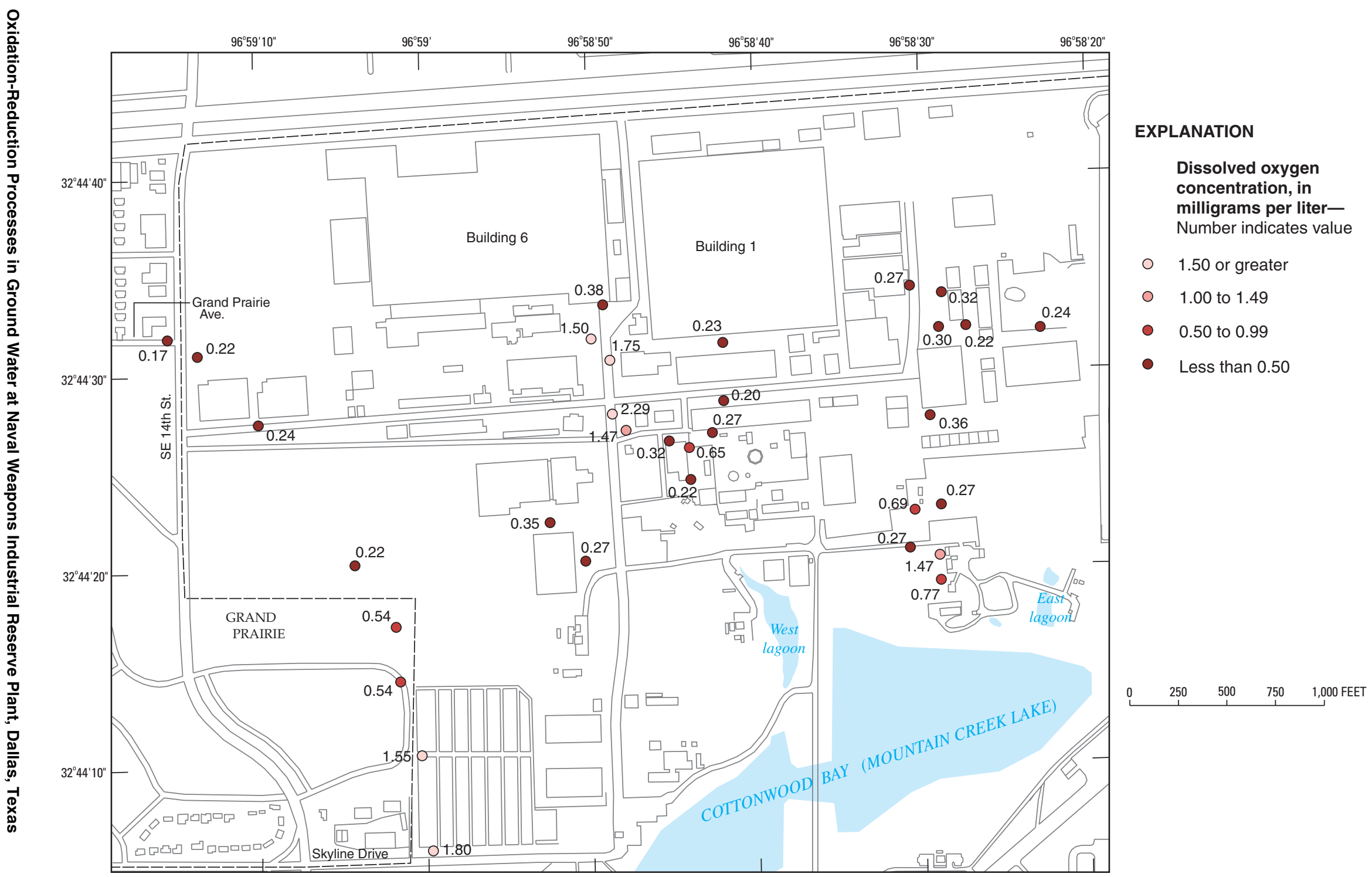

Figure 8. Dissolved oxygen concentrations from wells screened in the upper or in the upper and middle parts of the shallow alluvial deposits at the Naval Weapons Industrial Reserve Plant, Dallas, Texas, September 1997. 


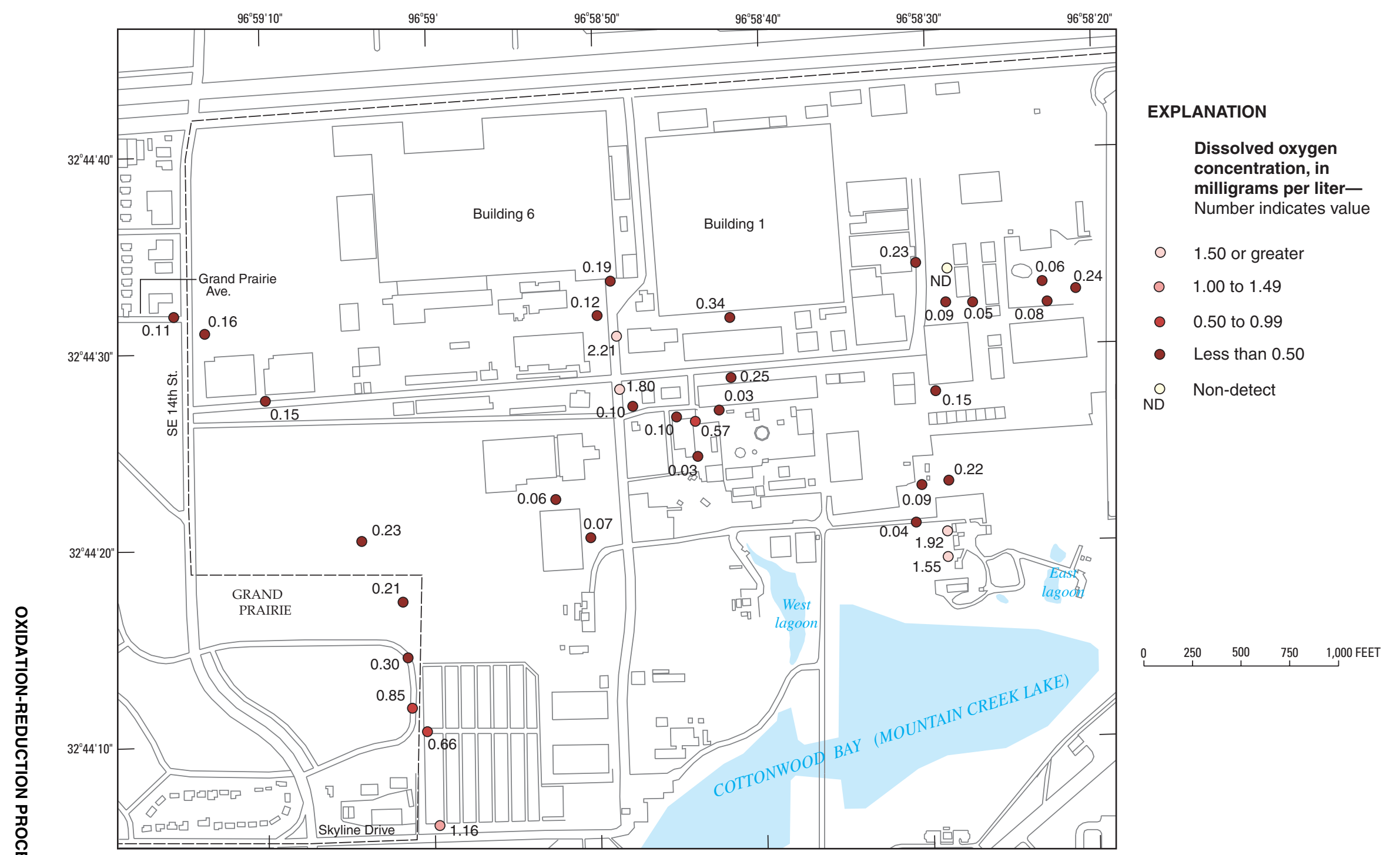

Figure 9. Dissolved oxygen concentrations from wells screened in the upper or in the upper and middle parts of the shallow alluvial deposits at the Naval Weapons Industrial Reserve Plant, Dallas, Texas, March 1998. 
DWP-L2-5 (fig. 10). The three "L2" wells are located south of building 6 , where nitrite (and nitrate) concentrations were larger than in most other areas of NWIRP. However, dissolved hydrogen concentrations indicate that the dominant redox process south of building 6 is ferric iron reduction.

Nitrate concentrations in uncontaminated shallow ground water generally are less than $2 \mathrm{mg} / \mathrm{L}$ (U.S. Geological Survey, 1999). Nitrate concentrations in wells DWP-L2-1, DWP-L2-16, and DWP-L2-5 were 25, 14.8 , and $8.4 \mathrm{mg} / \mathrm{L}$, respectively (appendix). The presence of nitrate at these relatively high concentrations, in addition to the larger DO concentrations, supports the possibility that an underground sewer pipe might be leaking south of building 6 .

\section{Ferrous Iron and Total Iron}

Ferric iron is reduced to ferrous iron by the reaction

$$
\begin{aligned}
\mathrm{CH}_{2} \mathrm{O}+ & 4 \mathrm{Fe}(\mathrm{OH})_{3}+7 \mathrm{H}^{+}=>4 \mathrm{Fe}^{+2}+\mathrm{HCO}_{3}^{-} \\
& +10 \mathrm{H}_{2} \mathrm{O} .
\end{aligned}
$$

Because of this process, an increase in ferrous iron concentration is expected where ferric iron reduction is occurring. Concentrations greater than about $1.00 \mathrm{mg} / \mathrm{L}$ indicate that iron reduction is probable (U.S. Environmental Protection Agency, 1993). The concentrations of ferrous iron in September 1997 and March 1998 (figs. 11, 12) indicate places where iron reduction probably is occurring, assuming that sulfide production from sulfate reduction is negligible.

\section{Sulfate and Sulfide}

Sulfate is reduced to hydrogen sulfide during sulfate reduction as follows:

$$
2 \mathrm{CH}_{2} \mathrm{O}+\mathrm{SO}_{4}^{-2}=>\mathrm{HCO}_{3}{ }^{-}+\mathrm{HS}^{-}+\mathrm{CO}_{2}+\mathrm{H}_{2} \mathrm{O} \text {. }
$$

Because of this process, an increase in sulfide is expected where sulfate reduction is occurring, assuming that locally, sulfide production exceeds iron reduction. The generally low concentrations of sulfide (figs. 13, 14) indicate that sulfate reduction is not a key process in the parts of the shallow alluvial deposits sampled.

\section{Dissolved Hydrogen}

Dissolved hydrogen concentrations (figs. 15, 16) indicate that ferric iron reduction is the most common redox process at the sampled wells. Dissolved hydrogen concentrations ranged from less than the method detection limit to more than 2,000 $\mathrm{nM}$ (table 4). Extremely large concentrations of hydrogen (greater than $50 \mathrm{nM}$ ) can be produced in newly installed wells, in wells pumped with direct-current-driven submersible pumps, and in wells with iron casing or screens (Chapelle and others, 1997). The relatively large hydrogen concentrations measured in this study are attributed to the installation of new wells. Excluding hydrogen concentrations greater than $50 \mathrm{nM}$, the median concentration of samples containing dissolved hydrogen was $0.53 \mathrm{nM}$ for samples collected in September 1997 and $0.45 \mathrm{nM}$ for samples collected in March 1998. These concentrations are typical indicators of ferric iron reduction (fig. 4).

Suarez and Rifai (1999) compiled a database of mean first-order decay rates for chlorinated solvents (table 5) from field and laboratory studies. From the table, the mean first-order decay rate associated with iron reduction for TCE is $0.003 \mathrm{day}^{-1}$. Using the general equation for first-order decay, $1 \mathrm{n}(0.5)=-\mathrm{kt}_{1 / 2}$, where $\mathrm{k}$ is the decay rate, and $t_{1 / 2}$ is the half-life, a mean half-life of 231 days is computed for TCE. The computed mean half-life for DCE in iron reducing conditions is 347 days and for VC is 2.7 days. Decay constants were not computed for NWIRP, but it is expected that decay rates at NWIRP would be similar to the decay rates thus computed.

\section{Total Organic Carbon}

Analytical screening criteria were developed by USEPA as part of a weighted scoring method to indicate where reductive dechlorination might be likely to occur (U.S. Environmental Protection Agency, 1998). (See next section.) The criterion for TOC is that $20 \mathrm{mg} / \mathrm{L}$ is required for reductive dechlorination to proceed efficiently. TOC concentrations at NWIRP ranged from less than the method detection limit to $11.9 \mathrm{mg} / \mathrm{L}$ in samples collected in September 1997 (appendix). Results of VOC analyses from September 1997 samples showed very few wells with anthropogenic carbon compounds such as benzene, toluene, ethylbenzene, or xylene. The lack of a sufficient organic carbon source, whether naturally occurring or anthropogenic, can be a limiting factor for efficient reductive dechlorination (Suarez and Rifai, 1999).

\section{Screening Results}

The USEPA has developed a weighted scoring method to indicate sites where reductive dechlorination 


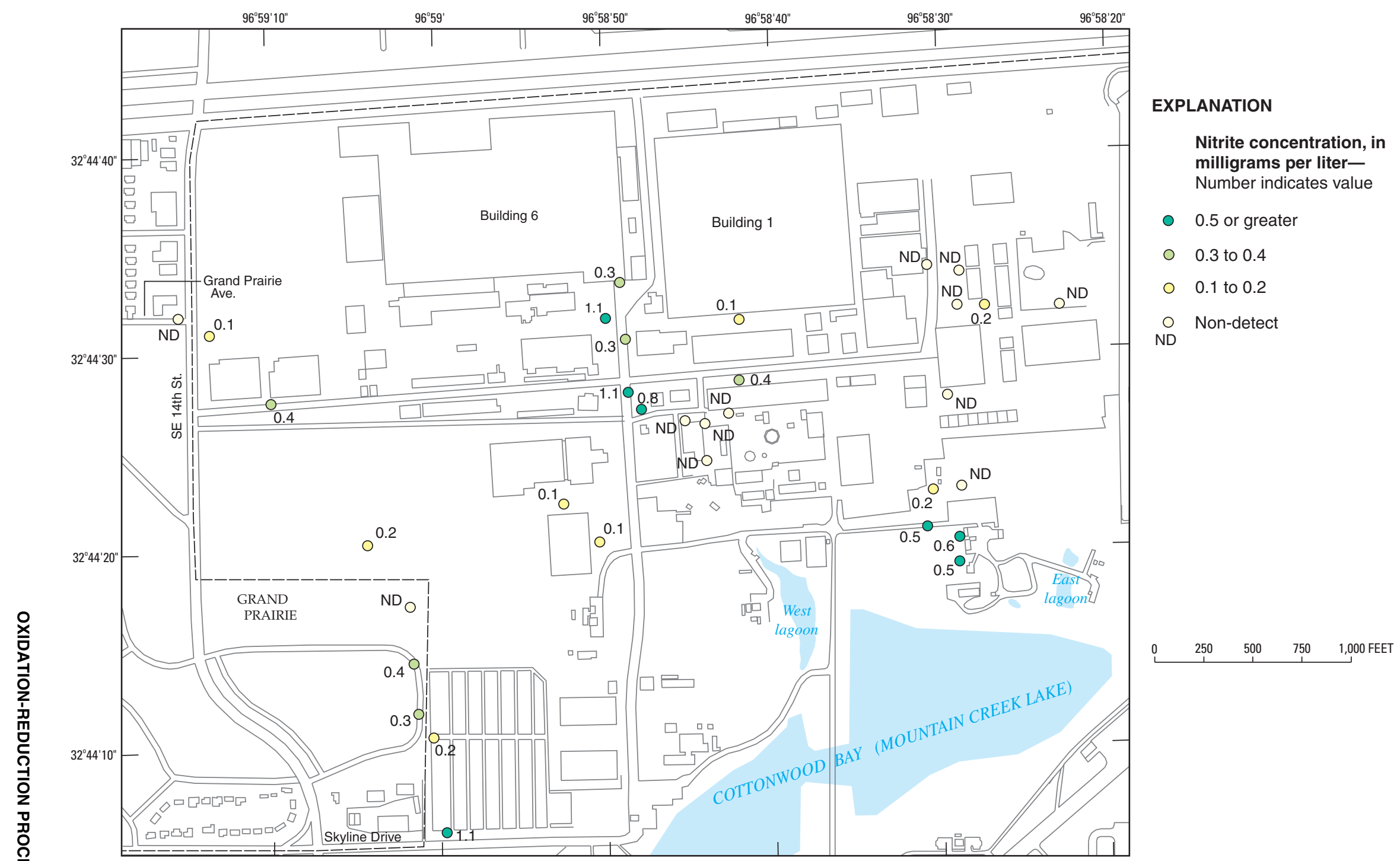

Figure 10. Nitrite concentrations from wells screened in the upper or in the upper and middle parts of the shallow alluvial deposits at the Naval

Weapons Industrial Reserve Plant, Dallas, Texas, September 1997. 


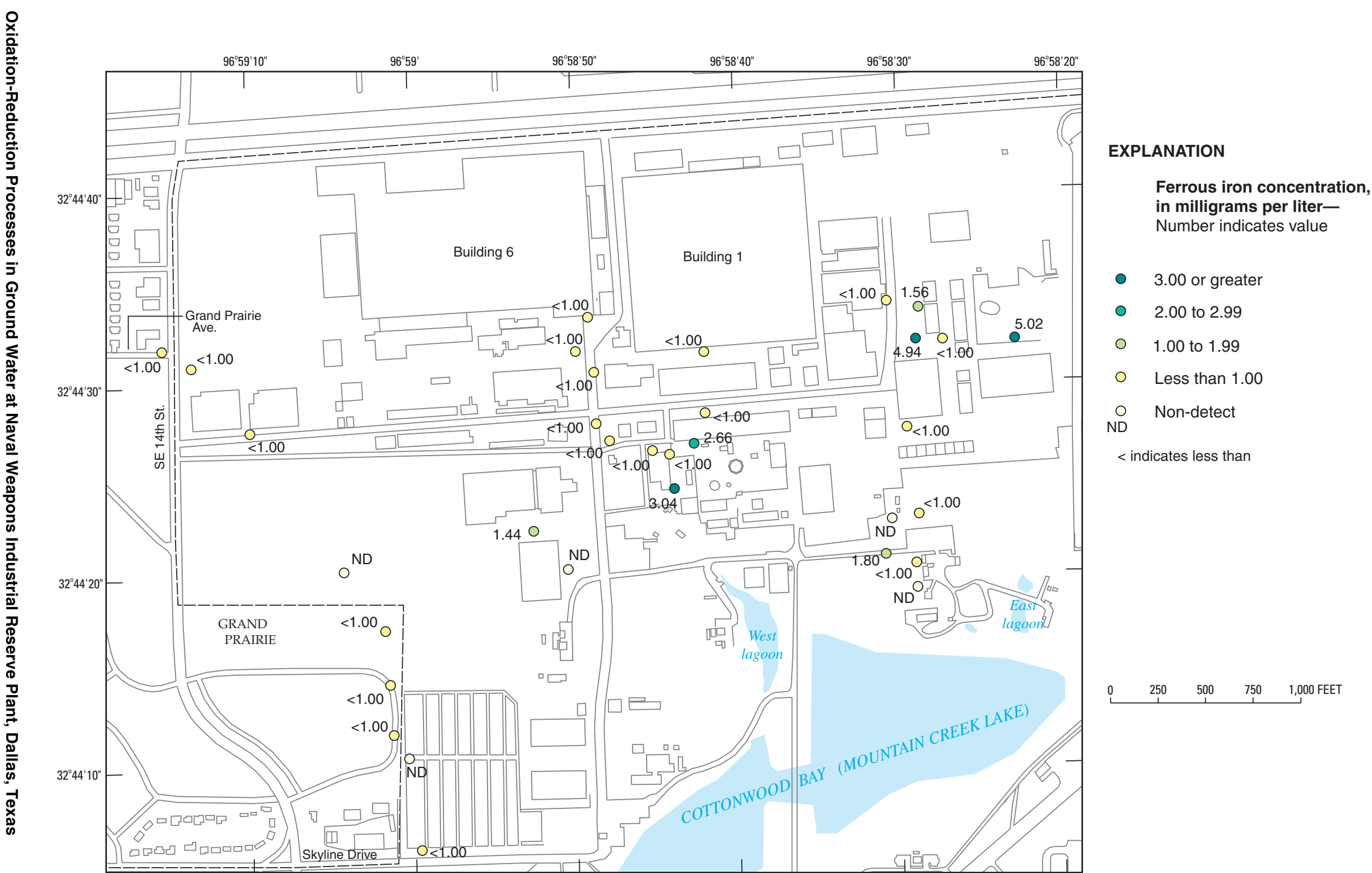

Figure 11. Ferrous iron concentrations from wells screened in the upper or in the upper and middle parts of the shallow alluvial deposits at the Naval Weapons Industrial Reserve Plant, Dallas, Texas, September 1997. 


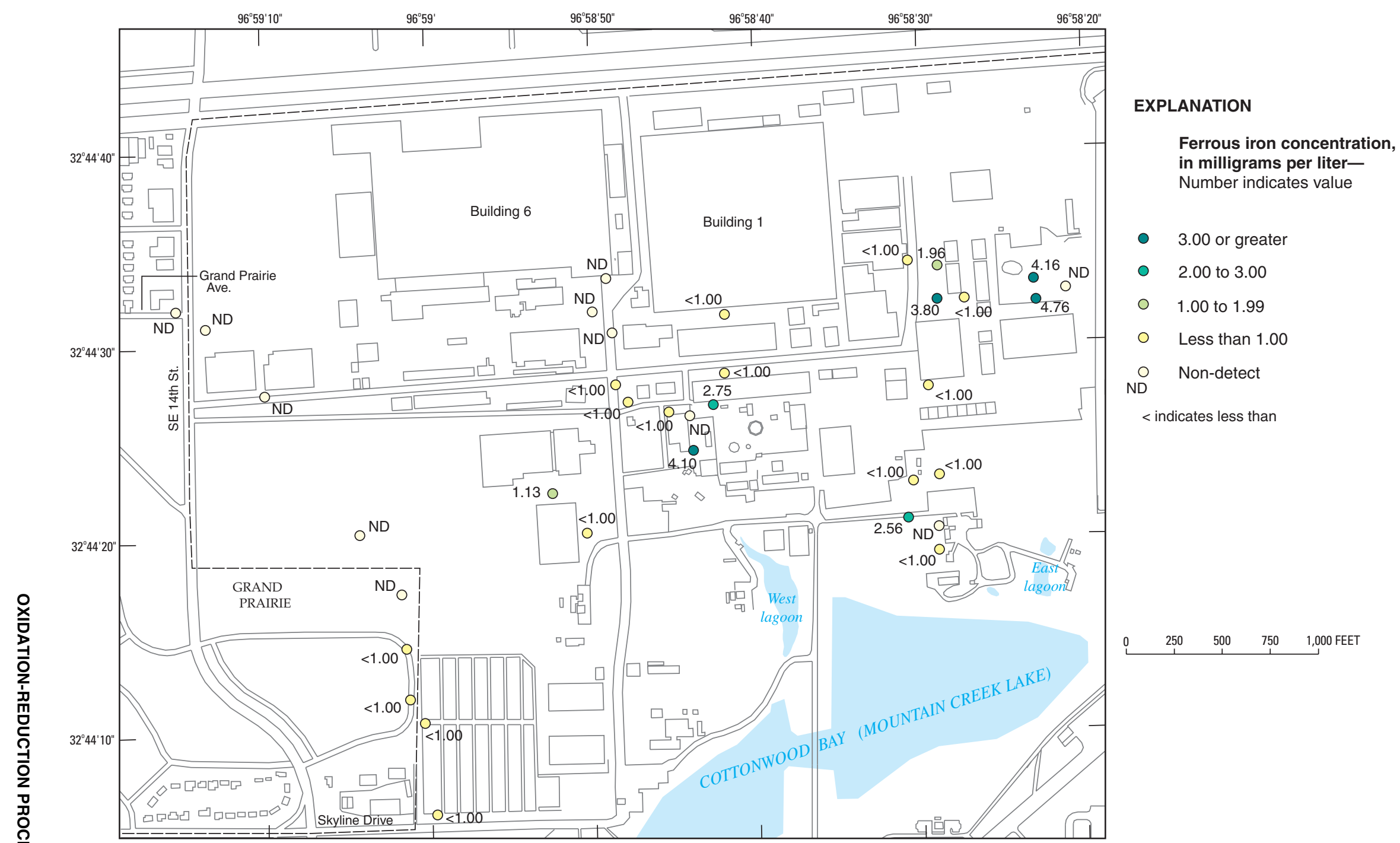

Figure 12. Ferrous iron concentrations from wells screened in the upper or in the upper and middle parts of the shallow alluvial deposits at the $\vec{v} \quad$ Naval Weapons Industrial Reserve Plant, Dallas, Texas, March 1998. 


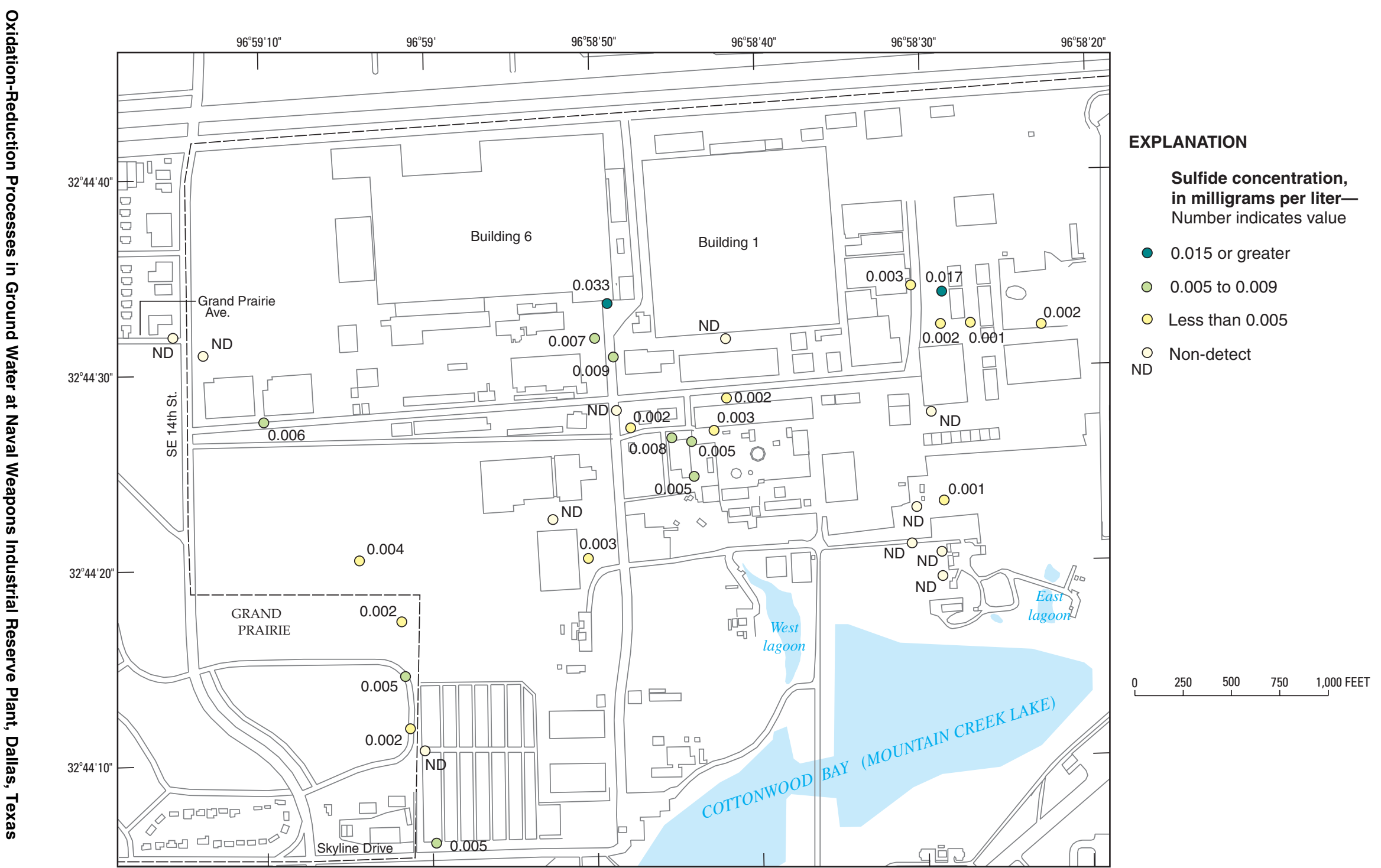

Figure 13. Sulfide concentrations from wells screened in the upper or in the upper and middle parts of the shallow alluvial deposits at the Naval Weapons Industrial Reserve Plant, Dallas, Texas, September 1997. 


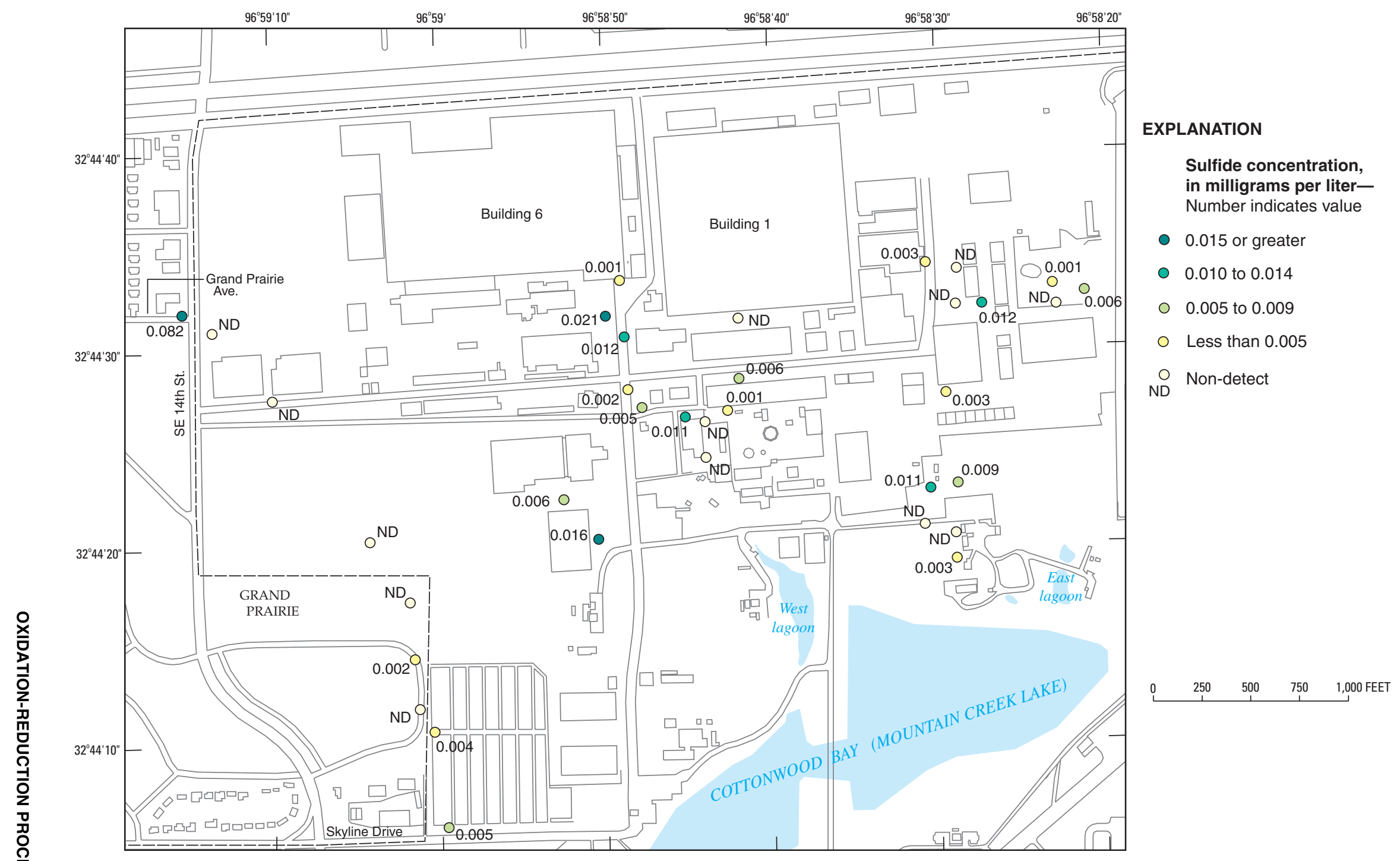

Figure 14. Sulfide concentrations from wells screened in the upper or in the upper and middle parts of the shallow alluvial deposits at the Naval

Weapons Industrial Reserve Plant, Dallas, Texas, March 1998. 


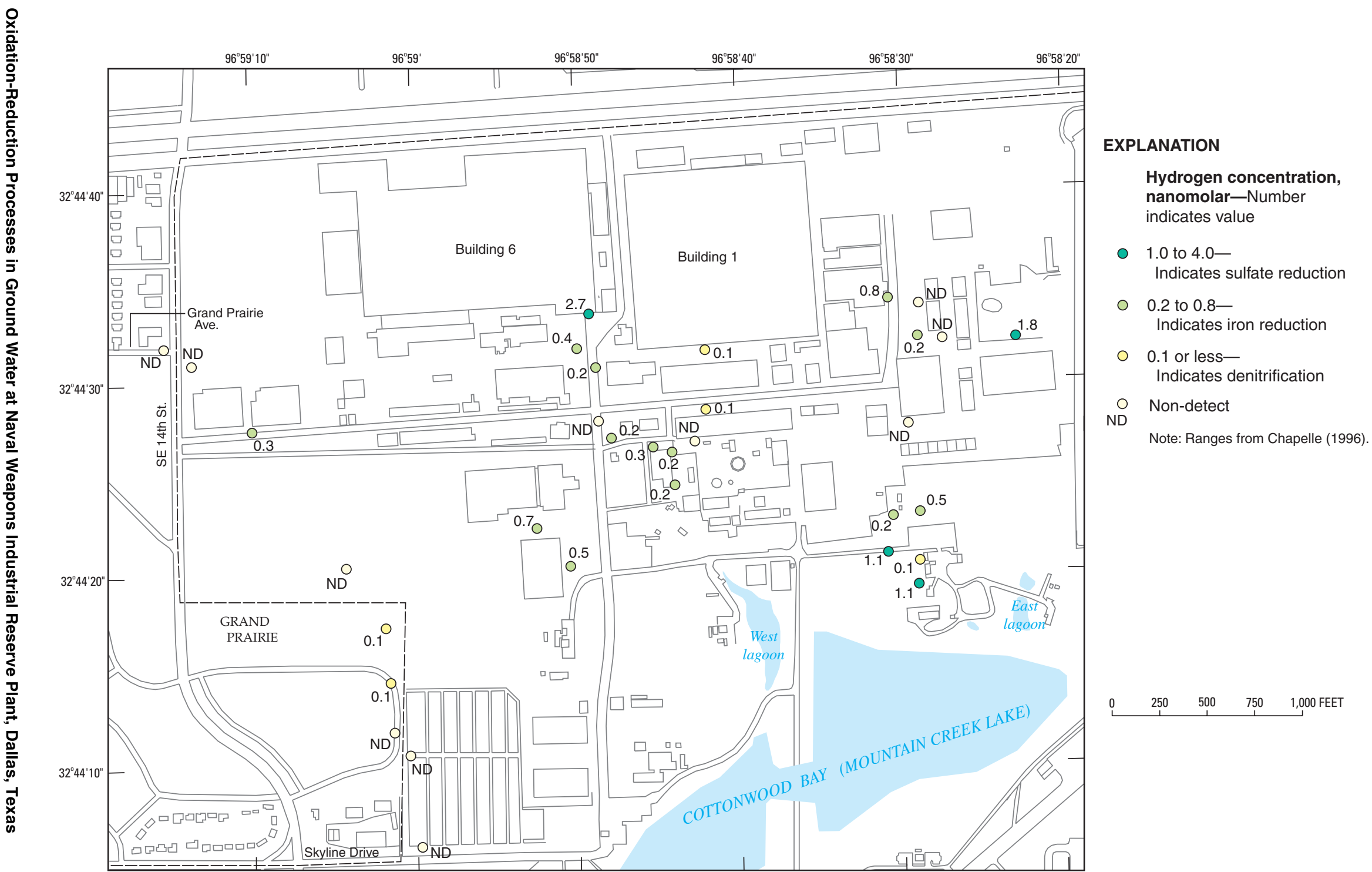

Figure 15. Dissolved hydrogen concentrations from wells screened in the upper or in the upper and middle parts of the shallow alluvial deposits and indicated oxidation-reduction processes at the Naval Weapons Industrial Reserve Plant, Dallas, Texas, September 1997. 


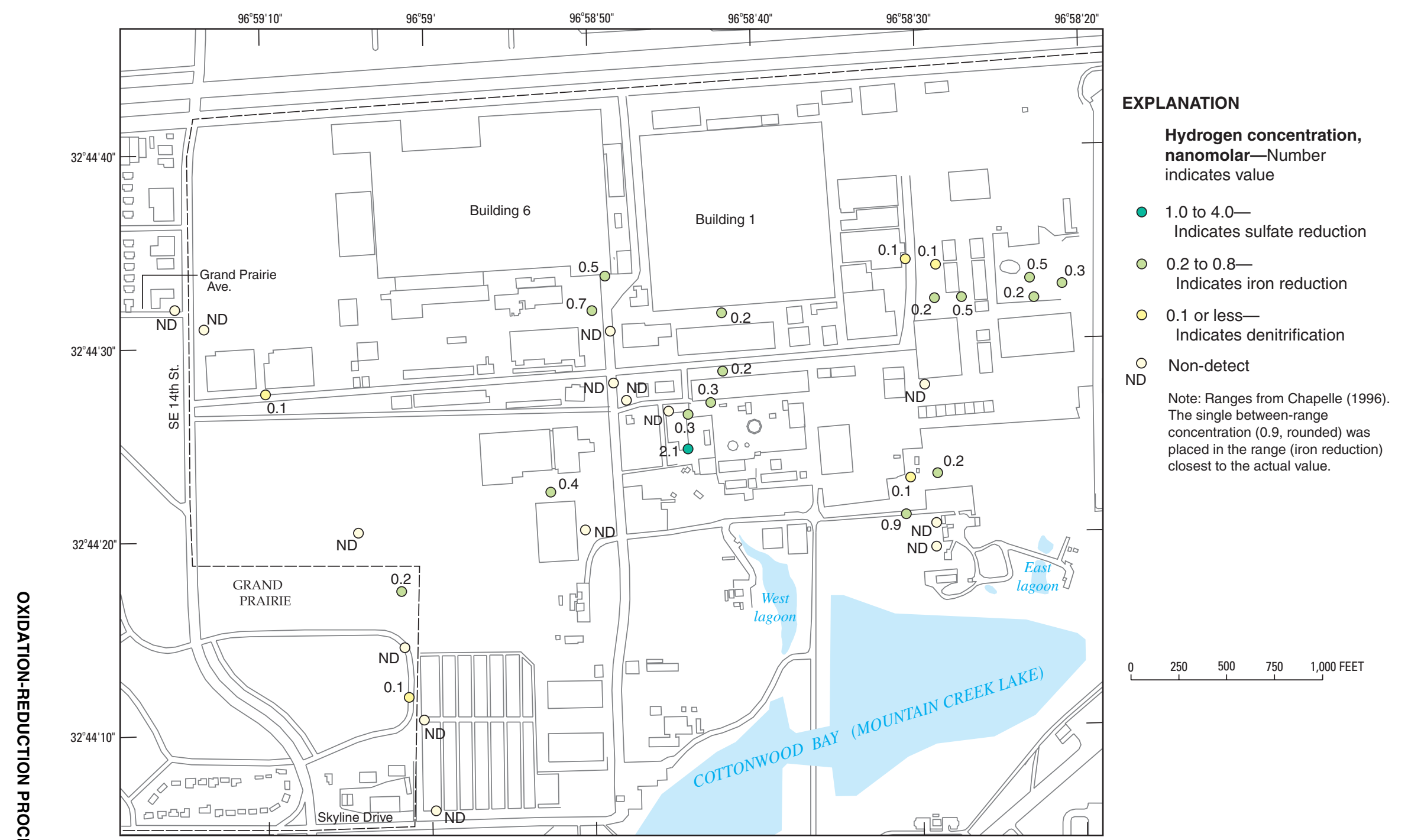

Figure 16. Dissolved hydrogen concentrations from wells screened in the upper or in the upper and middle parts of the shallow alluvial deposits and indicated oxidation-reduction processes at the Naval Weapons Industrial Reserve Plant, Dallas, Texas, March 1998. 
might be likely to occur (U.S. Environmental Protection Agency, 1998). Monitored natural attenuation (MNA) scores for sites (wells) are computed on the basis of concentrations of selected constituents. An MNA score of 0 to 5 of a possible 49 indicates inadequate evidence for anaerobic biodegradation of chlorinated solvents; a score of 6 to 14 indicates limited evidence for anaerobic biodegradation of chlorinated solvents; a score of 15 to 20 indicates adequate evidence for anaerobic biodegradation of chlorinated solvents; and a score greater than 20 indicates strong evidence for anaerobic biodegradation of chlorinated solvents. The work at NWIRP was done before the USEPA released its list of screening constituents; therefore not all the screening constituents were analyzed for this study. To score the ground-water samples collected from NWIRP in September 1997, a possible total score of 30 rather than 49 was used. Accordingly, the scoring also was modified-an MNA score of 0 to 3 indicated inadequate evidence for anaerobic biodegradation of chlorinated solvents; a score of 4 to 9 indicated limited evidence for anaerobic biodegradation of chlorinated solvents; a score of 10 to 12 indicated adequate evidence for anaerobic biodegradation of chlorinated solvents; and a score greater than 12 indicated strong evidence for anaerobic biodegradation of chlorinated solvents. The MNA score for each well is listed in table 3. Six wells had scores greater than 12. In general, scores were highest for samples collected on the northeast side of the facility, although three wells in the central part of the facility, DWP-5-12, DWP-S1-10, and DWP-S1-4 had scores greater than 12.

\section{SUMMARY}

Concentrations of TCE in ground water at NWIRP indicate three source areas of chlorinated solvents-building 1 , building 6 , and an off-site source west of the facility. The presence of cis-DCE and VC, products of reductive dechlorination of TCE that were not used at the facility, south and southwest of the source areas are evidence that reductive dechlorination is occurring.

The efficiency of reductive dechlorination in ground water is controlled by redox processes. The most common redox processes in ground water are the reduction of oxygen, nitrate (denitrification), ferric iron, sulfate, and carbon dioxide (methanogenesis). Concentrations of reduced species (for example, nitrite, ferrous iron) at a particular site can indicate which redox pro- cess is dominant, but sometimes concentrations of reduced species are not definitive. In such cases, concentrations of dissolved hydrogen in specific ranges can indicate which redox process is dominant. In places south of the source areas, DO concentrations indicated that reduction of oxygen could be the dominant process, particularly south of building 6; but elevated DO concentrations south of building 6 might be caused by a leaking water or sewer pipe. The nitrite data indicate that denitrification is occurring in places; however dissolved hydrogen concentrations indicate that iron reduction is the dominant process south of building 6 . The distributions of ferrous iron indicate that iron reduction is occurring in places south-southwest of buildings 6 and 1; dissolved hydrogen concentrations generally support the interpretation that iron reduction is the dominant process in those places. The generally low concentrations of sulfide indicate that sulfate reduction is not a key process in most sampled areas, an interpretation that is supported by dissolved hydrogen concentrations.

Dissolved hydrogen concentrations at sampled wells were most frequently in the range that indicated ferric iron reduction is the primary redox process. Applying mean first-order decay rates for TCE, cisDCE, and VC in iron-reducing conditions from a recent study resulted in mean half-lives for TCE, cis-DCE, and VC of 231, 347, and 2.67 days, respectively. Decay rates were not computed for NWIRP, but it is expected that decay rates, and thus half-lives, at NWIRP would be similar to those computed.

Small concentrations of TOC indicate the lack of an organic carbon source, which could be a limiting factor for efficient reductive dechlorination at NWIRP.

The USEPA has developed a weighted scoring method to indicate sites where reductive dechlorination might be likely to occur. At NWIRP, a score greater than 12 indicated strong evidence for anaerobic biodegradation of chlorinated solvents. Scores greater than 12 were computed for six sites. In general, scores were highest for samples collected on the northeast side of the facility, although three sites in the central part of NWIRP had scores greater than 12 .

\section{REFERENCES CITED}

Anaya, Roberto, Braun, C.L., and Kuniansky, E.L., 2000, Use of borehole geophysical logs for improved site characterization at Naval Weapons Industrial Reserve Plant, 
Dallas, Texas: U.S. Geological Survey Water-Resources Investigations Report 00-4150, $10 \mathrm{p}$.

Barker, R.A., and Braun, C.L., 2000, Computer-model analysis of ground-water flow and simulated effects of contaminant remediation at Naval Weapons Industrial Reserve Plant, Dallas, Texas: U.S. Geological Survey Water-Resources Investigations Report 00-4197, 44 p.

Bradley, P.M., and Chapelle, F.H., 1998, Microbial mineralization of VC and DCE under different terminal electron accepting conditions: Anaerobe, v. 4, p. 81-87.

Braun, C.L., Anaya, Roberto, and Kuniansky, E.L., 2000, Borehole geophysical logs at Naval Weapons Industrial Reserve Plant, Dallas, Texas: U.S. Geological Survey Open-File Report 00-076, 232 p.

Chapelle, F.H., 1996, Identifying redox conditions that favor the natural attenuation of chlorinated ethenes in contaminated ground-water systems, in Symposium on Natural Attenuation of Chlorinated Organics in Ground Water, Dallas, Tex., 1996, Proceedings: U.S. Environmental Protection Agency, EPA/540/R-96-509, p. 17-20.

Chapelle, F.H., Vroblesky, D.A., Woodward, J.C., and Lovley, D.R., 1997, Practical considerations for measuring hydrogen concentrations in groundwater: Environmental Science and Technology, v. 31, no. 10, p. 2,8732,877 .

EnSafe/Allen \& Hoshall, 1994, Comprehensive long-term environmental action-Navy stabilization work plan; Revision I: Prepared for Southern Division Naval Facilities Engineering Command, Charleston, S.C., 83 p.
1996, Draft RCRA facility investigation report, Naval Weapons Industrial Reserve Plant, Dallas, TexasVolume 1: Prepared for Southern Division Naval Facilities Engineering Command, Charleston, S.C., 135 p.

Gilbert, T.W., Behymer, T.D., and Castaneda, H.B., 1982, Determination of dissolved oxygen in natural and wastewaters: American Laboratory, American Society for Testing and Materials ASTM D 888-87, p. 119-134.

HACH Co., 1989, Water analysis handbook: Loveland, Colo., $691 \mathrm{p}$.

Suarez, M.P., and Rifai, H.S., 1999, Biodegradation rates for fuel hydrocarbons and chlorinated solvents in groundwater: Bioremediation Journal, v. 3, no. 4, p. 337-362.

Trace Analytical, 1997, RGA reduction gas analyzer operating manual: Menlo Park, Calif., 45 p.

U.S. Environmental Protection Agency, 1983, Methods for chemical analysis of water and wastes: EPA/600/4-74020 [variously paged]. 1993, Methods for determination of inorganic substances in environmental samples: EPA/600/R-93-100 [variously paged].

1998, Technical protocol for evaluating natural attenuation of chlorinated solvents in ground water: EPA/600/R-98-128, $233 \mathrm{p}$.

1999, Test methods for evaluating solid wastes, physical/chemical methods ( $3 \mathrm{~d}$ ed.): EPA/SW-846 [variously paged].

U.S. Geological Survey, 1999, The quality of our Nation's waters-Nutrients and pesticides: U.S. Geological Survey Circular 1225, 82 p. 
Table 1. Well information and sampling dates for wells sampled at the Naval Weapons Industrial Reserve Plant, Dallas, Texas

["Both" indicates that the screen penetrates both the upper and middle parts of the shallow alluvial aquifer]

\begin{tabular}{|c|c|c|c|c|c|c|}
\hline \multirow{2}{*}{$\begin{array}{c}\text { Well } \\
\text { number } \\
\text { (fig. 1) }\end{array}$} & \multicolumn{2}{|c|}{ Date sampled } & \multirow{2}{*}{$\begin{array}{l}\text { Well depth } \\
\text { (feet below } \\
\text { land surface) }\end{array}$} & \multirow{2}{*}{$\begin{array}{l}\text { Screened interval } \\
\text { (feet below } \\
\text { and surface) }\end{array}$} & \multirow{2}{*}{$\begin{array}{l}\text { Part of shallow } \\
\text { alluvial aquifer } \\
\text { in which well } \\
\text { is screened }\end{array}$} & \multirow{2}{*}{$\begin{array}{l}\text { Well altitude } \\
\text { (feet above } \\
\text { NGVD of 1929) }\end{array}$} \\
\hline & USGS & $\begin{array}{l}\text { EnSafe/ } \\
\text { Allen \& } \\
\text { Hoshall }\end{array}$ & & & & \\
\hline DWP-10-1 & 9/97 and 3/98 & $9 / 97$ & 24 & $8-23$ & Both & 486.6 \\
\hline DWP-10-2 & $3 / 98$ & -- & 29 & $13-28$ & Both & 486 \\
\hline DWP-10-6 & $3 / 98$ & -- & 24 & $13-23$ & Upper & 490 \\
\hline DWP-10-DW1 & $3 / 98$ & $9 / 97$ & 59 & $50-55$ & Lower & 486 \\
\hline DWP-10-DW4 & 9/97 and 3/98 & 9/97 & 64 & 59-64 & Lower & 490.1 \\
\hline DWP-10-DW6 & $3 / 98$ & $9 / 97$ & 54 & $34-54$ & Middle \& lower & 492 \\
\hline DWP-1-13 & 9/97 and 3/98 & $9 / 97$ & 19 & $3-18$ & Middle & 471.4 \\
\hline DWP-128-1 & 9/97 and 3/98 & $9 / 97$ & 25 & $4.5-24.5$ & Upper & 484.9 \\
\hline DWP-1-9 & 9/97 and 3/98 & $9 / 97$ & 29 & $13-28$ & Lower & 464.5 \\
\hline DWP-4-10 & 9/97 and 3/98 & $9 / 97$ & 14 & $3-13$ & Middle & 458.4 \\
\hline DWP-4-14 & 9/97 and 3/98 & $9 / 97$ & 22 & $10-20$ & Lower & 461.5 \\
\hline DWP-4-2 & 9/97 and 3/98 & -- & 22 & $11-21$ & Both & 479.7 \\
\hline DWP-4-4 & 9/97 and 3/98 & -- & 31 & $10-30$ & Both & 483.1 \\
\hline DWP-4-5 & 9/97 and 3/98 & $9 / 97$ & 29 & $13-28$ & Both & 490.2 \\
\hline DWP-4-8 & 9/97 and 3/98 & $9 / 97$ & 33 & $17-32$ & Both & 489.6 \\
\hline DWP-4-9 & 9/97 and 3/98 & $9 / 97$ & 29 & $13-28$ & Both & 476.6 \\
\hline DWP-5-12 & 9/97 and 3/98 & -- & 32 & $16-31$ & Upper & 488.7 \\
\hline DWP-5-13 & 9/97 and 3/98 & $9 / 97$ & 29 & $13-28$ & Both & 485.3 \\
\hline DWP-7-6 & 9/97 and 3/98 & -- & 32 & $15-25$ & Middle & 476.9 \\
\hline DWP-BG-10 & 9/97 and 3/98 & $9 / 97$ & 21 & $5-20$ & Both & 486.8 \\
\hline DWP-BG-4 & 9/97 and 3/98 & $9 / 97$ & 34 & $18-33$ & Middle & 501.7 \\
\hline DWP-BG-4-3 & 9/97 and 3/98 & $9 / 97$ & 28 & $18-28$ & Both & 503.2 \\
\hline DWP-BG-4-6 & 9/97 and 3/98 & $9 / 97$ & 30 & $15-30$ & Both & 500.2 \\
\hline DWP-BG-6 & 9/97 and 3/98 & -- & 39 & $23-38$ & Lower & 470.8 \\
\hline DWP-BG-7 & 9/97 and 3/98 & $9 / 97$ & 29 & $13-28$ & Upper & 499.6 \\
\hline DWP-BG-8 & 9/97 and 3/98 & -- & 19 & $3.5-18.5$ & Both & 478.9 \\
\hline DWP-DBG-3 & 9/97 and 3/98 & $9 / 97$ & 47 & $38-43$ & Lower & 479 \\
\hline DWP-L1-5 & 9/97 and 3/98 & $9 / 97$ & 34 & $18-33$ & Middle & 488.7 \\
\hline DWP-L2-1 & 9/97 and 3/98 & $9 / 97$ & 34 & $18-33$ & Upper & 496.6 \\
\hline DWP-L2-16 & 9/97 and 3/98 & $9 / 97$ & 29 & $13-28$ & Upper & 494.6 \\
\hline DWP-L2-4 & 9/97 and 3/98 & $9 / 97$ & 29 & $13-28$ & Upper & 494.6 \\
\hline DWP-L2-5 & 9/97 and 3/98 & -- & 27 & $11-26$ & Upper & 494.6 \\
\hline DWP-L2-8 & 9/97 and 3/98 & $9 / 97$ & 27 & $11-26$ & Upper & 494.9 \\
\hline DWP-L2-DW1 & 9/97 and 3/98 & $9 / 97$ & 60.5 & $55-60$ & Lower & 495 \\
\hline DWP-L2-DW2 & 9/97 and 3/98 & $9 / 97$ & 48 & $42-47$ & Middle & 495 \\
\hline
\end{tabular}


Table 1. Well information and sampling dates for wells sampled at the Naval Weapons Industrial Reserve Plant, Dallas, Texas-Continued

\begin{tabular}{ccccccc}
\hline $\begin{array}{c}\text { Well } \\
\text { number } \\
\text { (fig. 1) }\end{array}$ & USGS & $\begin{array}{c}\text { EnSafel } \\
\text { Allen } \begin{array}{c}\text { Dell depth } \\
\text { Hoshall }\end{array}\end{array}$ & $\begin{array}{c}\text { Dand surface) } \\
\text { (feet below }\end{array}$ & $\begin{array}{c}\text { Screened interval } \\
\text { (feet below } \\
\text { and surface) }\end{array}$ & $\begin{array}{c}\text { Part of shallow } \\
\text { alluvial aquifer } \\
\text { in which well } \\
\text { is screened }\end{array}$ & $\begin{array}{c}\text { Well altitude } \\
\text { (feet above } \\
\text { NGVD of 1929) }\end{array}$ \\
\cline { 2 - 5 } DWP-OFF-10 & $9 / 97$ and 3/98 & $9 / 97$ & 29 & $13-28$ & Upper & 495.3 \\
DWP-OFF-11 & $9 / 97$ and 3/98 & $9 / 97$ & 24 & $13-23$ & Both & 493.9 \\
DWP-OFF-12 & $3 / 98$ & $9 / 97$ & 24 & $16-23.5$ & Lower & 458 \\
DWP-OFF-14 & $3 / 98$ & $9 / 97$ & 20 & $13-18$ & Lower & 459 \\
DWP-OFF-5 & $9 / 97$ and 3/98 & $9 / 97$ & 34 & $18-33$ & Both & 501.8 \\
DWP-S1-10 & $9 / 97$ and 3/98 & $9 / 97$ & 29 & $13-28$ & Middle & 474.8 \\
DWP-S1-11 & $9 / 97$ and 3/98 & -- & 39 & $23-38$ & Middle & 486.5 \\
DWP-S1-17 & $9 / 97$ and 3/98 & $9 / 97$ & 29 & $21-26$ & Upper & 488.5 \\
DWP-S1-18 & $9 / 97$ and 3/98 & $9 / 97$ & 27 & $11-26$ & Upper & 487.6 \\
DWP-S1-4 & $9 / 97$ and 3/98 & $9 / 97$ & 32 & $13-31$ & Upper & 495.4 \\
DWP-S1-5 & $9 / 97$ and 3/98 & -- & 26 & $10-25$ & Upper & 485.0 \\
DWP-S1-7 & $9 / 97$ and 3/98 & $9 / 97$ & 30 & $14-29$ & Upper & 493.2 \\
DWP-S1-DW1 & $9 / 97$ and 3/98 & $9 / 97$ & 62.5 & $52-62$ & Lower & 489 \\
DWP-S1-DW2 & $9 / 97$ and 3/98 & -- & 48 & $38-45.5$ & Middle & 488 \\
DWP-S2-11 & $9 / 97$ and 3/98 & $9 / 97$ & 27 & $11-26$ & Upper & 491.2 \\
DWP-S2-16 & $9 / 97$ and 3/98 & $9 / 97$ & 29 & $13-28$ & Upper & 492 \\
DWP-S2-18 & $9 / 97$ and 3/98 & $9 / 97$ & 27 & $11-26$ & Both & 490 \\
DWP-S2-2 & $9 / 97$ and 3/98 & $9 / 97$ & 35 & $20-35$ & Upper & 494.7 \\
DWP-S2-5 & $9 / 97$ and 3/98 & $9 / 97$ & 33 & $17-32$ & Both & 491.5 \\
DWP-S2-DW1 & $9 / 97$ and 3/98 & $9 / 97$ & 71.5 & $62.5-67.5$ & Lower & 492 \\
DWP-S2-DW2 & $9 / 97$ and 3/98 & $9 / 97$ & 57 & $41-56$ & Middle & 492 \\
DWP-S5-10 & $9 / 97$ and 3/98 & $9 / 97$ & 32 & $15-30$ & Upper & 497.8 \\
\hline
\end{tabular}

Table 2. Selected constituents, methods, and procedures used to evaluate oxidation-reduction processes in ground water at the Naval Weapons Industrial Reserve Plant, Dallas, Texas

[GCMS, gas chromatography/mass spectroscopy]

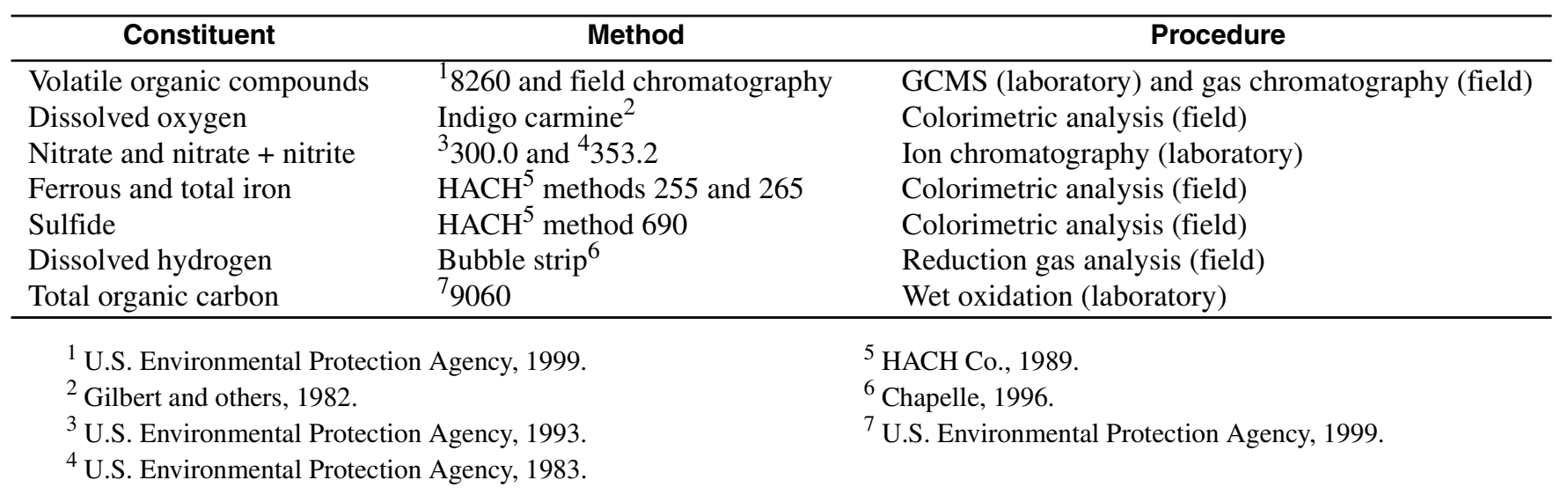


Table 3. Chemical results for selected volatile organic compounds from wells sampled at the Naval Weapons Industrial Reserve Plant, Dallas, Texas

[September 1997 data collected by EnSafe and analyzed by laboratory gas chromatograph/mass spectrometer; March 1998 data collected by USGS and analyzed by portable field gas chromatograph. $\mu \mathrm{g} / \mathrm{L}$, micrograms per liter; MNA, monitored natural attenuation; <, less than; ND, not detected; >, greater than; --, no data]

\begin{tabular}{|c|c|c|c|c|c|c|c|c|c|c|c|}
\hline \multirow[t]{2}{*}{$\begin{array}{c}\text { Well } \\
\text { number }\end{array}$} & \multicolumn{2}{|c|}{$\begin{array}{c}\text { Trichloro- } \\
\text { ethene } \\
(\mu \mathrm{g} / \mathrm{L})\end{array}$} & \multicolumn{2}{|c|}{$\begin{array}{c}\text { cis-1,2- } \\
\text { Dichloro- } \\
\text { ethene } \\
(\mu \mathrm{g} / L)\end{array}$} & \multicolumn{2}{|c|}{$\begin{array}{c}\text { trans-1,2- } \\
\text { Dichloro- } \\
\text { ethene } \\
(\mu \mathrm{g} / \mathrm{L})\end{array}$} & \multicolumn{2}{|c|}{$\begin{array}{c}\text { Vinyl } \\
\text { chloride } \\
(\mu \mathrm{g} / \mathrm{L})\end{array}$} & \multicolumn{2}{|c|}{$\begin{array}{c}\text { Ratio of } \\
\text { trichloroethene } \\
\text { to cis-1,2- } \\
\text { dichloroethene }\end{array}$} & \multirow{2}{*}{$\begin{array}{c}\text { MNA } \\
\text { score } \\
9 / 97\end{array}$} \\
\hline & 9/97 & $3 / 98$ & 9/97 & $3 / 98$ & $9 / 97$ & $3 / 98$ & 9/97 & $3 / 98$ & $9 / 97$ & $3 / 98$ & \\
\hline DWP-10-1 & 36 & 12 & $<10$ & ${ }^{1} 6$ & $<10$ & ND & $<10$ & 12 & $>3.6$ & 0.3 & 14 \\
\hline DWP-10-2 & -- & 50 & -- & 54 & -- & ND & -- & 94 & -- & .9 & -- \\
\hline DWP-10-6 & -- & 450 & -- & $1_{4}$ & -- & ND & -- & ND & -- & 112.5 & -- \\
\hline DWP-10-DW1 & ${ }^{2} 52,000$ & 13,000 & ${ }^{2} 960$ & 7,900 & ${ }^{19}$ & $1_{3}$ & ${ }^{1} 46$ & 13 & 54.2 & 1.6 & -- \\
\hline DWP-10-DW4 & ${ }^{2} 3,000$ & 27 & ${ }^{2} 680$ & ${ }^{1} 8$ & ${ }^{1} 11$ & ND & $1_{27}$ & ND & 4.4 & 3.4 & 10 \\
\hline DWP-10-DW6 & 15,000 & 5,000 & ${ }^{1} 320$ & 47 & $<1,000$ & $1_{2}$ & $<1,000$ & ND & 46.9 & 106.4 & -- \\
\hline DWP-1-13 & ${ }^{2} 180$ & 220 & 2350 & 300 & 13 & 10 & ${ }^{1} 20$ & $1_{3}$ & .5 & .7 & 10 \\
\hline DWP-128-1 & ${ }^{2} 940$ & 29 & ${ }^{2} 200$ & 12 & $1_{2}$ & ${ }^{1} 1$ & 63 & $1_{2}$ & 4.7 & 2.4 & 11 \\
\hline DWP-1-9 & 260 & 350 & 180 & 350 & 5 & 5 & 32 & 7 & 1.4 & 1.0 & 10 \\
\hline DWP-4-10 & ND & 5 & 130 & 150 & ${ }^{1} .8$ & ${ }^{1} 1$ & 61 & 33 & 0 & 0 & 10 \\
\hline DWP-4-14 & 180 & 110 & 240 & 140 & ${ }^{1} 8$ & $1_{4}$ & 80 & 7 & .8 & .8 & 10 \\
\hline DWP-4-2 & -- & 250 & -- & 160 & -- & 10 & -- & ND & -- & 1.6 & -- \\
\hline DWP-4-4 & -- & 16 & -- & 1,900 & -- & 8 & -- & 84 & -- & 0 & 12 \\
\hline DWP-4-5 & 3,100 & 2,200 & ${ }^{1} 280$ & 230 & $<500$ & 15 & $<500$ & $1_{4}$ & 11.1 & 9.6 & 3 \\
\hline DWP-4-8 & 510 & 310 & 540 & 350 & $1_{29}$ & 13 & $<50$ & ${ }^{1} 1$ & .9 & .9 & 6 \\
\hline DWP-4-9 & 420 & 310 & 200 & 130 & ${ }^{1} 23$ & 10 & $<50$ & ND & 2.1 & 2.4 & 5 \\
\hline DWP-5-12 & -- & 27 & -- & 5 & -- & ND & -- & ${ }^{1} 1$ & -- & 5.4 & 14 \\
\hline DWP-5-13 & ${ }^{2} 510$ & 660 & ${ }^{1} 86$ & 95 & ${ }^{19}$ & 8 & $1_{7}$ & ${ }^{1} 1$ & 5.9 & 6.9 & 12 \\
\hline DWP-7-6 & -- & 260 & -- & 78 & -- & 4 & -- & ${ }^{1} 1$ & -- & 3.3 & 4 \\
\hline DWP-BG-10 & 120 & 170 & $<10$ & ND & $<10$ & ND & $<10$ & ND & $>12.0$ & $>170.0$ & -- \\
\hline DWP-BG-4 & 680 & 640 & 63 & 55 & $<50$ & ND & $<50$ & ND & 10.8 & 11.6 & 8 \\
\hline DWP-BG-4-3 & 110 & 66 & 11 & 6 & $<10$ & ND & $<10$ & ND & 10.0 & 11.0 & 8 \\
\hline DWP-BG-4-6 & ${ }^{1} 9$ & 20 & $<10$ & ND & $<10$ & ND & $<10$ & ND & $>.9$ & $>20.0$ & 4 \\
\hline DWP-BG-6 & -- & 33 & -- & $1_{2}$ & -- & ND & -- & ND & -- & 16.5 & 4 \\
\hline DWP-BG-7 & 590 & 450 & 28 & 36 & $<50$ & $1_{3}$ & $<50$ & ND & 21.1 & 12.5 & 3 \\
\hline DWP-BG-8 & -- & 9 & -- & ND & -- & ND & -- & ND & -- & $>9.0$ & 1 \\
\hline DWP-DBG-3 & -- & 7 & -- & ${ }^{1} 1$ & -- & ND & -- & ND & -- & 7.0 & 12 \\
\hline DWP-L1-5 & $\mathrm{ND}$ & 390 & $<10$ & 280 & $<10$ & ND & $<10$ & ND & 0 & 1.4 & 11 \\
\hline DWP-L2-1 & 3,000 & 1,400 & 300 & 220 & $<200$ & ND & $<200$ & ND & 10.0 & 6.4 & 3 \\
\hline DWP-L2-16 & ${ }^{2} 1,200$ & 290 & ${ }^{2} 220$ & 170 & 1 & ND & $<10$ & ND & 5.5 & 1.7 & 3 \\
\hline DWP-L2-4 & 27,000 & 12,000 & ${ }^{1} 310$ & 230 & $<2,000$ & 2 & $<2,000$ & ND & 87.1 & 52.2 & 3 \\
\hline DWP-L2-5 & -- & 450 & -- & 6 & -- & ND & -- & ND & -- & 75.0 & 4 \\
\hline
\end{tabular}

Footnotes at end of table. 
Table 3. Chemical results for selected volatile organic compounds from wells sampled at the Naval Weapons Industrial Reserve Plant, Dallas, Texas—Continued

\begin{tabular}{|c|c|c|c|c|c|c|c|c|c|c|c|}
\hline \multirow[t]{2}{*}{$\begin{array}{c}\text { Well } \\
\text { number }\end{array}$} & \multicolumn{2}{|c|}{$\begin{array}{l}\text { Trichloro- } \\
\text { ethene } \\
(\mu \mathrm{g} / \mathrm{L})\end{array}$} & \multicolumn{2}{|c|}{$\begin{array}{c}\text { cis-1,2- } \\
\text { Dichloro- } \\
\text { ethene } \\
(\mu \mathrm{g} / \mathrm{L})\end{array}$} & \multicolumn{2}{|c|}{$\begin{array}{c}\text { trans-1,2- } \\
\text { Dichloro- } \\
\text { ethene } \\
(\mu \mathrm{g} / \mathrm{L})\end{array}$} & \multicolumn{2}{|c|}{$\begin{array}{c}\text { Vinyl } \\
\text { chloride } \\
(\mu \mathrm{g} / \mathrm{L})\end{array}$} & \multicolumn{2}{|c|}{$\begin{array}{c}\text { Ratio of } \\
\text { trichloroethene } \\
\text { to cis-1,2- } \\
\text { dichloroethene }\end{array}$} & \multirow{2}{*}{$\begin{array}{r}\text { MNA } \\
\text { score } \\
9 / 97\end{array}$} \\
\hline & $9 / 97$ & $3 / 98$ & 9/97 & $3 / 98$ & 9/97 & $3 / 98$ & 9/97 & $3 / 98$ & $9 / 97$ & $3 / 98$ & \\
\hline DWP-L2-8 & 5,600 & 3,200 & 65 & 90 & $<500$ & ND & $<500$ & ND & 86.2 & 35.6 & 11 \\
\hline DWP-L2-DW1 & 200 & 350 & $1_{3}$ & 25 & $<20$ & 1 & $<20$ & ND & 66.7 & 14.0 & 3 \\
\hline DWP-L2-DW2 & 4,500 & 2,200 & ${ }^{1} 25$ & 620 & $<250$ & ND & $<250$ & ND & 180.0 & 3.5 & 8 \\
\hline DWP-OFF-10 & ${ }^{2} 420$ & 620 & ${ }^{1} 1$ & $1_{4}$ & $<10$ & ND & $<10$ & ND & -- & 155.0 & 5 \\
\hline DWP-OFF-11 & ${ }^{2} 270$ & 340 & $<10$ & ${ }^{1} 1$ & $<10$ & ND & $<10$ & ND & $>27.0$ & 340.0 & -- \\
\hline DWP-OFF-12 & 36 & 58 & 22 & 15 & ${ }^{1} 1$ & ${ }^{1} 1$ & $<10$ & ND & 1.6 & 3.9 & -- \\
\hline DWP-OFF-14 & 16 & 23 & 14 & 11 & ${ }^{1} 1$ & ND & $1_{2}$ & ND & 1.1 & 2.1 & -- \\
\hline DWP-OFF-5 & 13,000 & 6,800 & 4,500 & 2,700 & $<1,000$ & 8 & $<1,000$ & 24 & 2.9 & 2.5 & 8 \\
\hline DWP-S1-10 & ${ }^{2} 14,000$ & 5,600 & ${ }^{2} 970$ & 520 & 100 & 33 & 170 & 10 & 14.4 & 10.8 & 13 \\
\hline DWP-S1-11 & -- & 700 & -- & 17 & -- & ${ }^{1} 1$ & -- & ND & -- & 41.2 & 9 \\
\hline DWP-S1-17 & $1_{2}$ & 27 & $<10$ & 16 & $<10$ & $1_{3}$ & $<10$ & 10 & 0 & 1.7 & 9 \\
\hline DWP-S1-18 & 24,600 & 2,400 & 2430 & 320 & 10 & 3 & 66 & $1_{3}$ & 10.7 & 7.5 & 10 \\
\hline DWP-S1-4 & ${ }^{2} 440$ & 290 & 23 & 15 & $<10$ & ND & 27 & ${ }^{1} 1$ & 19.1 & 19.3 & 14 \\
\hline DWP-S1-5 & -- & 8 & -- & 3,200 & -- & 410 & -- & ND & -- & 0 & -- \\
\hline DWP-S1-7 & 23 & 45 & $<10$ & 2 & $<10$ & ND & $<10$ & ND & $>2.3$ & 22.5 & 6 \\
\hline DWP-S1-DW1 & ${ }^{1} .5$ & 66 & $<10$ & ${ }^{1} 2$ & $<10$ & ND & $<10$ & ND & 0 & 33.0 & 6 \\
\hline DWP-S1-DW2 & $<10$ & 9 & $<10$ & ND & $<10$ & ND & $<10$ & ND & 1.0 & $>9.0$ & 6 \\
\hline DWP-S2-11 & ${ }^{1} 400$ & 150 & ${ }^{2} 2,700$ & 1,100 & 64 & 14 & ${ }^{1} 86$ & ${ }^{1} 3$ & .1 & .1 & 12 \\
\hline DWP-S2-16 & ${ }^{2} 3,400$ & 4,300 & ${ }^{2} 9,300$ & 1,100 & ${ }^{1} 47$ & 37 & ${ }^{2} 420$ & 180 & .4 & 3.9 & 16 \\
\hline DWP-S2-18 & ${ }^{2} 720$ & 1,030 & 130 & 134 & ${ }^{1} 5$ & $1_{3}$ & ${ }^{1} 7$ & ${ }^{1} 2$ & 5.5 & 7.7 & 10 \\
\hline DWP-S2-2 & 13 & 46 & 180 & 150 & 26 & 19 & ${ }^{1} 3$ & 2 & .1 & .3 & 10 \\
\hline DWP-S2-5 & $<10$ & ND & ${ }^{2} 1,500$ & 540 & $1_{36}$ & 7 & ${ }^{2} 4,400$ & 170 & 0 & 0 & 16 \\
\hline DWP-S2-DW1 & $1_{7}$ & 18 & $1_{4}$ & 21 & $<10$ & ND & $<10$ & 550 & 1.8 & .9 & 11 \\
\hline DWP-S2-DW2 & ${ }^{1} 430$ & 17 & ${ }^{1} 41$ & 270 & $<10$ & ND & $<10$ & ${ }^{1} 2$ & 10.5 & .1 & 5 \\
\hline DWP-S5-10 & 240 & 210 & $<10$ & ${ }^{1} 1$ & $<10$ & ND & $<10$ & ND & $>24.0$ & 210.0 & 4 \\
\hline
\end{tabular}

${ }^{1}$ Estimated.

${ }^{2}$ Sample diluted during analysis. 
Table 4. Selected field and laboratory data from wells sampled at the Naval Weapons Industrial Reserve Plant, Dallas, Texas

[Nitrite data from laboratory, all other data analyzed from unfiltered samples in the field. $\mathrm{mg} / \mathrm{L}$, milligrams per liter; $\mathrm{nM}$, nanomolar; ND, not detected; --, no data]

\begin{tabular}{|c|c|c|c|c|c|c|c|c|c|c|}
\hline \multirow{2}{*}{$\begin{array}{c}\text { Well } \\
\text { number }\end{array}$} & \multicolumn{2}{|c|}{$\begin{array}{c}\text { Dissolved } \\
\text { oxygen } \\
\text { (mg/L) }\end{array}$} & \multicolumn{2}{|c|}{$\begin{array}{l}\text { Nitrite } \\
\text { (mg/L) }\end{array}$} & \multicolumn{2}{|c|}{$\begin{array}{l}\text { Ferrous } \\
\text { iron } \\
(\mathrm{mg} / \mathrm{L})\end{array}$} & \multicolumn{2}{|c|}{$\begin{array}{l}\text { Sulfide } \\
\text { (mg/L) }\end{array}$} & \multicolumn{2}{|c|}{$\begin{array}{l}\text { Dissolved } \\
\text { hydrogen } \\
\text { (nM) }\end{array}$} \\
\hline & 9/97 & $3 / 98$ & 9/97 & $3 / 98$ & 9/97 & $3 / 98$ & $9 / 97$ & $3 / 98$ & $9 / 97$ & $3 / 98$ \\
\hline DWP-10-1 & 0.24 & 0.08 & ND & -- & 5.02 & ${ }^{1} 4.76$ & 0.002 & ND & 1.8 & 0.2 \\
\hline DWP-10-2 & -- & .06 & -- & -- & -- & ${ }^{1} 4.16$ & -- & .001 & -- & .5 \\
\hline DWP-10-6 & -- & .24 & -- & -- & -- & $\mathrm{ND}$ & -- & .006 & -- & .3 \\
\hline DWP-10-DW1 & -- & 1.28 & -- & -- & -- & .90 & -- & ND & -- & .6 \\
\hline DWP-10-DW4 & .19 & .14 & ND & -- & .84 & 1.22 & .003 & .007 & ND & .3 \\
\hline DWP-10-DW6 & -- & .06 & -- & -- & -- & .10 & -- & .008 & -- & $\mathrm{ND}$ \\
\hline DWP-1-13 & .14 & ${ }^{2} .04$ & ND & -- & ${ }^{3} .02$ & ND & .001 & .002 & ND & .1 \\
\hline DWP-128-1 & .22 & ${ }^{2} .03$ & ND & -- & ${ }^{1} 3.04$ & ${ }^{1} 4.10$ & .005 & ND & .2 & 2.1 \\
\hline DWP-1-9 & .20 & .45 & .6 & -- & ${ }^{3} .10$ & $\mathrm{ND}$ & .002 & .001 & ND & .2 \\
\hline DWP-4-10 & .44 & ${ }^{2} .04$ & ND & -- & .14 & .02 & ND & .001 & .4 & .2 \\
\hline DWP-4-14 & .27 & .13 & .2 & -- & ND & ND & ND & ND & .2 & ND \\
\hline DWP-4-2 & 1.47 & 1.92 & 6 & -- & .01 & ND & ND & ND & .1 & ND \\
\hline DWP-4-4 & .27 & ${ }^{2} .04$ & .5 & -- & 1.8 & 2.56 & ND & ND & 1.1 & .9 \\
\hline DWP-4-5 & .69 & .09 & .2 & -- & ND & .05 & ND & .011 & .2 & .1 \\
\hline DWP-4-8 & .27 & .22 & ND & -- & .04 & .02 & .001 & .009 & .5 & .2 \\
\hline DWP-4-9 & .77 & 1.55 & .5 & -- & ND & .04 & ND & .003 & 1.1 & ND \\
\hline DWP-5-12 & .35 & .06 & .1 & -- & 1.44 & 1.13 & ND & .006 & .7 & .4 \\
\hline DWP-5-13 & .27 & .07 & .1 & -- & ND & .06 & .003 & .016 & .5 & ND \\
\hline DWP-7-6 & .20 & .34 & .4 & -- & 3.10 & ND & .003 & .006 & ND & .3 \\
\hline DWP-BG-10 & 1.55 & .66 & .2 & -- & ND & .04 & ND & .004 & ND & ND \\
\hline DWP-BG-4 & .15 & .78 & .2 & -- & .02 & ND & .001 & ND & ND & ND \\
\hline DWP-BG-4-3 & .22 & .16 & .1 & -- & .03 & ND & ND & ND & ND & ND \\
\hline DWP-BG-4-6 & .24 & .15 & .4 & -- & ${ }^{3} .09$ & ND & .006 & ND & .3 & .1 \\
\hline DWP-BG-6 & .32 & .16 & ND & -- & .01 & ND & ND & ND & ND & .1 \\
\hline DWP-BG-7 & .54 & .21 & ND & -- & .02 & ND & .002 & ND & .1 & .2 \\
\hline DWP-BG-8 & 1.8 & 1.16 & 1.1 & -- & .05 & .02 & .005 & .005 & ND & ND \\
\hline DWP-DBG-3 & .19 & ${ }^{2} .02$ & .8 & -- & 1.78 & 1.18 & .014 & ND & 1.3 & 1.8 \\
\hline DWP-L1-5 & .32 & .15 & .3 & -- & .75 & ${ }^{1} 1.16$ & .007 & .004 & .5 & 1.7 \\
\hline DWP-L2-1 & 2.29 & 1.80 & 1.1 & -- & 3.37 & .02 & ND & .002 & ND & ND \\
\hline DWP-L2-16 & 1.47 & .10 & .8 & -- & ${ }^{3} .06$ & .04 & .002 & .005 & .2 & $\mathrm{ND}$ \\
\hline DWP-L2-4 & 1.75 & 2.21 & .3 & -- & ${ }^{3} .19$ & ND & .009 & .012 & .2 & ND \\
\hline DWP-L2-5 & 1.50 & .12 & 1.1 & -- & ${ }^{3} .16$ & ND & .007 & .021 & .4 & .7 \\
\hline
\end{tabular}

Footnotes at end of table. 
Table 4. Selected field and laboratory data from wells sampled at the Naval Weapons Industrial Reserve Plant, Dallas, Texas-Continued

\begin{tabular}{|c|c|c|c|c|c|c|c|c|c|c|}
\hline \multirow[t]{2}{*}{$\begin{array}{c}\text { Well } \\
\text { number }\end{array}$} & \multicolumn{2}{|c|}{$\begin{array}{c}\text { Dissolved } \\
\text { oxygen } \\
\text { (mg/L) }\end{array}$} & \multicolumn{2}{|c|}{$\begin{array}{l}\text { Nitrite } \\
\text { (mg/L) }\end{array}$} & \multicolumn{2}{|c|}{$\begin{array}{c}\text { Ferrous } \\
\text { iron } \\
(\mathrm{mg} / \mathrm{L})\end{array}$} & \multicolumn{2}{|c|}{$\begin{array}{l}\text { Sulfide } \\
\text { (mg/L) }\end{array}$} & \multicolumn{2}{|c|}{$\begin{array}{c}\text { Dissolved } \\
\text { hydrogen } \\
\text { (nM) }\end{array}$} \\
\hline & 9/97 & $3 / 98$ & 9/97 & $3 / 98$ & 9/97 & $3 / 98$ & 9/97 & $3 / 98$ & 9/97 & $3 / 98$ \\
\hline DWP-L2-8 & 0.38 & 0.19 & 0.3 & -- & 0.03 & ND & 0.033 & 0.001 & 2.7 & 0.5 \\
\hline DWP-L2-DW1 & 1.24 & .16 & .3 & -- & ${ }^{3} .13$ & .03 & .002 & ND & .1 & 2.4 \\
\hline DWP-L2-DW2 & .54 & .26 & .4 & -- & .12 & .53 & .001 & .055 & 7.3 & .3 \\
\hline DWP-OFF-10 & .54 & .30 & .4 & -- & ${ }^{3} .10$ & .02 & .005 & .002 & .1 & ND \\
\hline DWP-OFF-11 & -- & .85 & .3 & -- & ${ }^{3} .14$ & .02 & .002 & ND & ND & .1 \\
\hline DWP-OFF-12 & -- & 1.67 & -- & -- & -- & .06 & -- & .001 & -- & .7 \\
\hline DWP-OFF-14 & -- & .24 & -- & -- & -- & .08 & -- & ND & -- & 1 \\
\hline DWP-OFF-5 & .17 & .11 & ND & -- & .01 & ND & ND & .082 & ND & ND \\
\hline DWP-S1-10 & .27 & .13 & .4 & -- & ${ }^{3} .12$ & .02 & .004 & .003 & .15 & 1.0 \\
\hline DWP-S1-11 & .22 & .22 & .4 & -- & ${ }^{3} .17$ & ND & .012 & .012 & 1.9 & .5 \\
\hline DWP-S1-17 & .27 & ${ }^{2} .03$ & ND & -- & 2.66 & 2.75 & .003 & .001 & ND & .3 \\
\hline DWP-S1-18 & .32 & .10 & ND & -- & ${ }^{3} .15$ & .03 & .008 & .011 & .3 & ND \\
\hline DWP-S1-4 & .2 & .25 & .4 & -- & .01 & .05 & .002 & .006 & .14 & .2 \\
\hline DWP-S1-5 & .65 & .57 & ND & -- & ${ }^{3} .12$ & ND & .005 & ND & .2 & .3 \\
\hline DWP-S1-7 & .23 & .34 & .1 & -- & ${ }^{3} .03$ & .01 & ND & ND & .1 & .2 \\
\hline DWP-S1-DW1 & .32 & .06 & ND & -- & .86 & .88 & .021 & ND & 2.0 & .2 \\
\hline DWP-S1-DW2 & .32 & .05 & ND & -- & ND & .03 & ND & .021 & ${ }^{4} 670$ & ${ }^{4} 2,100$ \\
\hline DWP-S2-11 & .36 & .15 & ND & -- & .16 & .02 & ND & .003 & ND & ND \\
\hline DWP-S2-16 & .32 & ND & ND & -- & 1.56 & 1.96 & .017 & ND & ND & .1 \\
\hline DWP-S2-18 & .22 & .05 & .2 & -- & .01 & .03 & .001 & .012 & ND & .5 \\
\hline DWP-S2-2 & .27 & .23 & ND & -- & .31 & .16 & .003 & .003 & .8 & .1 \\
\hline DWP-S2-5 & .3 & .09 & ND & -- & ${ }^{1} 4.94$ & ${ }^{1} 3.80$ & .002 & ND & .2 & .2 \\
\hline DWP-S2-DW1 & .54 & ${ }^{2} .04$ & ND & -- & 2.02 & 1.15 & .024 & ND & ${ }^{4} 290$ & .9 \\
\hline DWP-S2-DW2 & 1.14 & .20 & ND & -- & .37 & 1.72 & .006 & .003 & .6 & 2.4 \\
\hline DWP-S5-10 & .22 & .23 & .2 & -- & ND & ND & .004 & ND & ND & ND \\
\hline
\end{tabular}

${ }^{1}$ Sample diluted during analysis.

${ }^{2}$ Estimated.

${ }^{3}$ Erroneous value because of cloudy sample.

${ }^{4}$ Erroneous value because of new well construction. 
Table 5. Mean first-order decay rates and computed half-lives for trichloroethene, dichloroethene, and vinyl chloride under five oxidation-reduction conditions (Suarez and Rifai, 1999)

$[--$, no data $]$

\begin{tabular}{lcccccc}
\hline \multicolumn{1}{c}{$\begin{array}{c}\text { Oxidation-reduction } \\
\text { condition }\end{array}$} & $\begin{array}{c}\text { Trichloro- } \\
\text { ethene } \\
\text { day }\end{array}$ & $\begin{array}{c}\text { Half-life } \\
\text { (days) }\end{array}$ & $\begin{array}{c}\text { Dichloro- } \\
\text { ethene } \\
\text { (all isomers) } \\
\text { day }^{-1}\end{array}$ & $\begin{array}{c}\text { Half-life } \\
\text { (days) }\end{array}$ & $\begin{array}{c}\text { Vinyl } \\
\text { chloride } \\
\text { day }^{-1}\end{array}$ & $\begin{array}{c}\text { Half-life } \\
\text { (days) }\end{array}$ \\
\hline Oxygen reduction (aerobic oxidation) & 0.005 & 139 & -- & -- & 0.087 & 7.97 \\
Nitrate reduction (denitrification) & -- & -- & -- & -- & -- & -- \\
Iron reduction & .003 & 231 & 0.002 & 347 & .26 & 2.67 \\
Sulfate reduction & .011 & 63 & .045 & 15.4 & -- & -- \\
Carbon dioxide reduction (methanogenesis) & .015 & 46.2 & .047 & 14.7 & .23 & 3.01 \\
\hline
\end{tabular}


Oxidation-Reduction Processes in Ground Water at Naval Weapons Industrial Reserve Plant, Dallas, Texas

Appendix-Data

Appendix-Data 


\begin{tabular}{|c|c|c|c|c|c|c|c|c|c|c|}
\hline \multicolumn{5}{|c|}{ September 1997} & \multicolumn{6}{|c|}{ March 1998} \\
\hline Well number & $\begin{array}{c}\text { Specific } \\
\text { conductance } \\
(\mu \mathrm{S})\end{array}$ & $\begin{array}{c}\text { pH } \\
\text { (standard } \\
\text { units) }\end{array}$ & $\begin{array}{c}\text { Carbon } \\
\text { dioxide } \\
\left(\mathrm{mM} \mathrm{CO}_{2}\right)\end{array}$ & $\begin{array}{l}\text { Methane } \\
\left(\mu \mathrm{M} \mathrm{CH}_{4}\right)\end{array}$ & Well number & $\begin{array}{c}\text { Specific } \\
\text { conductance } \\
(\mu \mathrm{S})\end{array}$ & $\begin{array}{c}\mathrm{pH} \\
\text { (standard } \\
\text { units) }\end{array}$ & $\begin{array}{c}\text { Alkalinity, } \\
\text { bicarbonate } \\
\left(\mathrm{mg} / \mathrm{L} \mathrm{HCO}_{3}\right)\end{array}$ & $\begin{array}{l}\text { Carbon } \\
\text { dioxide } \\
\left.(\mathrm{mM} \mathrm{CO})_{2}\right)\end{array}$ & $\begin{array}{l}\text { Methane } \\
\left(\mu \mathrm{M} \mathrm{CH}_{4}\right)\end{array}$ \\
\hline DWP-10-1 & 950 & 6.88 & 0.01 & ND & DWP-10-1 & 703 & 6.61 & 455 & 1.62 & 291.2 \\
\hline DWP-10-DW4 & 910 & 6.77 & .48 & ND & DWP-10-2 & 846 & 7.25 & 478 & 1.28 & 371.3 \\
\hline DWP-1-13 & 6,080 & 7.51 & 1.77 & 7.87 & DWP-10-6 & 720 & 7.13 & 405 & 1.18 & ND \\
\hline DWP-128-1 & 930 & 6.74 & 2.17 & 34.20 & DWP-10-DW1 & 1,103 & 7.40 & 401 & .66 & .3 \\
\hline DWP-1-9 & 970 & 7.39 & 1.57 & ND & DWP-10-DW4 & 1,178 & 7.08 & 398 & .42 & ND \\
\hline DWP-4-10 & 1,150 & 6.6 & 3.75 & .87 & DWP-10-DW6 & 803 & 7.22 & 371 & 1.00 & ND \\
\hline DWP-4-14 & 1,030 & 6.56 & 2.21 & ND & DWP-1-13 & 1,101 & 6.95 & 528 & 1.55 & 3.9 \\
\hline DWP-4-2 & -- & -- & 2.23 & ND & DWP-128-1 & 1,104 & 6.94 & 638 & 2.48 & 234.5 \\
\hline DWP-4-4 & -- & -- & 1.94 & 61.49 & DWP-1-9 & 1,126 & 6.50 & 459 & 1.47 & ND \\
\hline DWP-4-5 & 1,160 & 6.75 & 2.28 & .46 & DWP-4-10 & 1,220 & 6.82 & 646 & 3.09 & 35.5 \\
\hline DWP-4-8 & 920 & 7.9 & 1.22 & ND & DWP-4-14 & 1,122 & 6.73 & 485 & 2.43 & 3.7 \\
\hline DWP-4-9 & 1,210 & 6.61 & 2.67 & ND & DWP-4-2 & 1,228 & 6.81 & 516 & 2.13 & ND \\
\hline DWP-5-12 & 705 & 6.86 & 1.20 & 72.12 & DWP-4-4 & 995 & 6.77 & 520 & 1.85 & 97.1 \\
\hline DWP-5-13 & 677 & 6.77 & 1.29 & .57 & DWP-4-5 & 1,160 & 6.79 & 559 & 2.15 & ND \\
\hline DWP-7-6 & -- & -- & 1.89 & 2.86 & DWP-4-8 & 930 & 6.99 & 476 & 1.15 & ND \\
\hline DWP-BG-10 & 830 & 6.74 & 2.33 & ND & DWP-4-9 & 1,210 & 6.84 & 540 & 2.13 & ND \\
\hline DWP-BG-4 & 1,160 & 7.91 & 1.19 & ND & DWP-5-12 & 802 & 6.92 & 450 & .41 & 102.5 \\
\hline DWP-BG-4-3 & 1,030 & 6.79 & 1.58 & ND & DWP-5-13 & 798 & 6.81 & 379 & 1.13 & .7 \\
\hline DWP-BG-4-6 & 1,190 & 7.72 & 1.10 & ND & DWP-7-6 & 976 & 6.80 & 469 & 1.36 & ND \\
\hline DWP-BG-6 & 798 & 6.43 & 1.94 & ND & DWP-BG-10 & 1,036 & 6.58 & 521 & 2.38 & ND \\
\hline DWP-BG-7 & 1,240 & 6.61 & 2.84 & ND & DWP-BG-4 & 1,028 & 6.97 & 418 & 1.09 & ND \\
\hline DWP-BG-8 & 1,050 & 7.84 & 2.11 & ND & DWP-BG-4-3 & 1,090 & 6.80 & 481 & 1.59 & ND \\
\hline DWP-DBG-3 & 1,050 & 7.84 & 1.39 & ND & DWP-BG-4-6 & 1,002 & 6.95 & 479 & 1.29 & ND \\
\hline DWP-L1-5 & 717 & 6.86 & .69 & 447.55 & DWP-BG-6 & 924 & 6.98 & 428 & 1.85 & ND \\
\hline DWP-L2-1 & 741 & 6.96 & 1.08 & ND & DWP-BG-7 & 1,138 & 6.86 & 516 & 3.13 & ND \\
\hline DWP-L2-16 & 757 & 7.02 & .74 & ND & DWP-BG-8 & 1,031 & 7.11 & 513 & 1.50 & ND \\
\hline DWP-L2-4 & -- & -- & .36 & ND & DWP-DBG-3 & 991 & 6.85 & 447 & 1.32 & ND \\
\hline DWP-L2-5 & -- & -- & 1.19 & ND & DWP-L1-5 & 700 & 7.07 & 455 & .70 & 935.2 \\
\hline
\end{tabular}


Field data collected by the USGS, September 1997 and March 1998-Continued

\begin{tabular}{|c|c|c|c|c|c|c|c|c|c|c|}
\hline \multicolumn{5}{|c|}{ September 1997} & \multicolumn{6}{|c|}{ March 1998} \\
\hline Well number & $\begin{array}{c}\text { Specific } \\
\text { conductance } \\
(\mu \mathrm{S})\end{array}$ & $\begin{array}{c}\text { pH } \\
\text { (standard } \\
\text { units) }\end{array}$ & $\begin{array}{l}\text { Carbon } \\
\text { dioxide } \\
\left(\mathrm{mM} \mathrm{CO}_{2}\right)\end{array}$ & $\begin{array}{l}\text { Methane } \\
\left(\mu \mathrm{M} \mathrm{CH}_{4}\right)\end{array}$ & Well number & $\begin{array}{c}\text { Specific } \\
\text { conductance } \\
(\mu S)\end{array}$ & $\begin{array}{c}\text { pH } \\
\text { (standard } \\
\text { units) }\end{array}$ & $\begin{array}{c}\text { Alkalinity, } \\
\text { bicarbonate } \\
\left(\mathrm{mg} / \mathrm{L} \mathrm{HCO}_{3}\right)\end{array}$ & $\begin{array}{l}\text { Carbon } \\
\text { dioxide } \\
\left(\mathrm{mM} \mathrm{CO}_{2}\right)\end{array}$ & $\begin{array}{l}\text { Methane } \\
\left.(\mu \mathrm{M} \mathrm{CH})_{4}\right)\end{array}$ \\
\hline DWP-L2-8 & 980 & 6.93 & ND & ND & DWP-L2-1 & 949 & 7.22 & 327 & 1.63 & ND \\
\hline DWP-L2-DW1 & 1,620 & 11.08 & .10 & ND & DWP-L2-16 & 937 & 6.90 & 504 & 1.02 & ND \\
\hline DWP-L2-DW2 & 825 & 7.14 & 1.01 & 6.66 & DWP-L2-4 & 613 & 7.12 & 216 & .34 & ND \\
\hline DWP-OFF-10 & 921 & 6.68 & 2.68 & ND & DWP-L2-5 & 1,055 & 6.95 & 385 & 1.16 & ND \\
\hline DWP-OFF-11 & 1,240 & 6.59 & 3.34 & ND & DWP-L2-8 & 1,020 & 6.84 & 413 & 1.63 & ND \\
\hline DWP-OFF-5 & 1,490 & 6.33 & 2.01 & 2.89 & DWP-L2-DW1 & 4,000 & 11.84 & 289 & ND & .5 \\
\hline DWP-S1-10 & 865 & 6.67 & 1.51 & 32.34 & DWP-L2-DW2 & 889 & 7.02 & 411 & 1.17 & 142.2 \\
\hline DWP-S1-11 & -- & -- & 1.28 & ND & DWP-OFF-10 & 1,169 & 6.87 & 529 & 2.84 & ND \\
\hline DWP-S1-17 & 628 & 6.98 & 3.08 & 3.75 & DWP-OFF-11 & 1,194 & 6.87 & 546 & 2.89 & ND \\
\hline DWP-S1-18 & 734 & 6.6 & .99 & ND & DWP-OFF-12 & 905 & 6.93 & 481 & 2.60 & 493.2 \\
\hline DWP-S1-4 & 734 & 6.79 & 2.26 & 6.71 & DWP-OFF-14 & 903 & 7.91 & 496 & .76 & .9 \\
\hline DWP-S1-5 & -- & -- & 1.34 & ND & DWP-OFF-5 & 1,557 & 7.00 & 498 & 2.21 & 1.5 \\
\hline DWP-S1-7 & 1,170 & 7.33 & 1.81 & ND & DWP-S1-10 & 921 & 6.78 & 470 & 1.42 & 37.7 \\
\hline DWP-S1-DW1 & -- & -- & .95 & ND & DWP-S1-11 & 870 & 6.89 & 423 & 1.27 & ND \\
\hline DWP-S1-DW2 & -- & -- & .01 & ND & DWP-S1-17 & 683 & 7.09 & 368 & 1.15 & 34.7 \\
\hline DWP-S2-11 & 950 & 7.65 & 2.43 & 3.62 & DWP-S1-18 & 787 & 6.90 & 397 & .94 & .8 \\
\hline DWP-S2-16 & 960 & 6.87 & 1.93 & 43.60 & DWP-S1-4 & 924 & 6.95 & 334 & 2.00 & ND \\
\hline DWP-S2-18 & 765 & 6.75 & 1.96 & ND & DWP-S1-5 & 849 & 7.19 & 403 & 1.27 & ND \\
\hline DWP-S2-2 & 936 & 7.6 & 1.73 & .93 & DWP-S1-7 & 950 & 6.87 & 433 & 1.67 & ND \\
\hline DWP-S2-5 & 699 & 6.95 & 2.08 & 132.75 & DWP-S1-DW1 & 792 & 7.23 & 411 & .92 & 6 \\
\hline DWP-S2-DW1 & 1,510 & 7.03 & .59 & ND & DWP-S1-DW2 & 1,497 & 11.63 & 78 & ND & 14.2 \\
\hline DWP-S2-DW2 & 756 & 7.09 & .46 & ND & DWP-S2-11 & 1,031 & 6.79 & 456 & 2.29 & ND \\
\hline \multirow[t]{7}{*}{ DWP-S5-10 } & 1,240 & 6.71 & 2.83 & ND & DWP-S2-16 & 920 & 6.95 & 501 & 1.82 & 78.9 \\
\hline & & & & & DWP-S2-18 & 931 & 6.80 & 516 & 1.88 & ND \\
\hline & & & & & DWP-S2-2 & 1,005 & 6.88 & 491 & 1.72 & 1.9 \\
\hline & & & & & DWP-S2-5 & 923 & 6.80 & 518 & 2.25 & 439.4 \\
\hline & & & & & DWP-S2-DW1 & 1,584 & 7.13 & 420 & .60 & 214.0 \\
\hline & & & & & DWP-S2-DW2 & 1,231 & 7.01 & 395 & 1.46 & 1.4 \\
\hline & & & & & DWP-S5-10 & 1,038 & 6.83 & 520 & 2.24 & ND \\
\hline
\end{tabular}




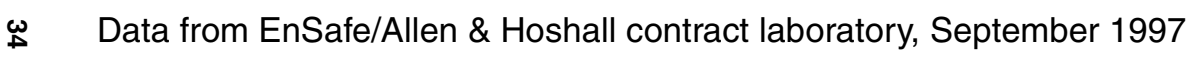

\begin{tabular}{|c|c|c|c|c|c|c|c|c|c|c|c|c|c|}
\hline $\begin{array}{c}\text { Well } \\
\text { number }\end{array}$ & $\begin{array}{l}\text { Dissolved } \\
\text { solids, } \\
\text { calculated } \\
\text { (mg/L) }\end{array}$ & $\begin{array}{c}\text { Calcium } \\
\text { (mg/L) }\end{array}$ & $\begin{array}{l}\text { Magne- } \\
\text { sium } \\
\text { (mg/L) }\end{array}$ & $\begin{array}{l}\text { Sodium } \\
\text { (mg/L) }\end{array}$ & $\begin{array}{l}\text { Potas- } \\
\text { sium } \\
(\mathrm{mg} / \mathrm{L})\end{array}$ & $\begin{array}{l}\text { Iron } \\
\text { (mg/L) }\end{array}$ & $\begin{array}{c}\text { Manga- } \\
\text { nese } \\
\text { (mg/L) }\end{array}$ & $\begin{array}{c}\text { Tetrachlo- } \\
\text { roethene } \\
(\mu \mathrm{g} / \mathrm{L})\end{array}$ & $\begin{array}{l}\text { 1,1-Dichlo- } \\
\text { roethene } \\
(\mu \mathrm{g} / \mathrm{L})\end{array}$ & $\begin{array}{c}1,1,1- \\
\text { Trichlo- } \\
\text { roethane } \\
(\mu \mathrm{g} / \mathrm{L})\end{array}$ & $\begin{array}{l}\text { 1,1-Dichlo- } \\
\text { roethane } \\
(\mu \mathrm{g} / \mathrm{L})\end{array}$ & $\begin{array}{c}\text { Benzene } \\
(\mu \mathrm{g} / \mathrm{L})\end{array}$ & $\begin{array}{c}\text { Toluene } \\
(\mu \mathrm{g} / \mathrm{L})\end{array}$ \\
\hline DWP-10-1 & 416 & 82.3 & 13.5 & 48.7 & 1.47 & 11.3 & 0.795 & ND & ND & ND & ND & ND & ND \\
\hline DWP-10-DW1 & -- & 103 & 11 & 120 & 3.30 & 3.36 & .336 & 7 & ND & ND & 9 & ND & 7 \\
\hline DWP-10-DW4 & 771 & 117 & 8 & 84.6 & 1.54 & .267 & .386 & ND & ND & ND & ND & ND & ND \\
\hline DWP-10-DW6 & -- & 99 & 5.44 & 81.4 & 3.75 & 1.56 & .196 & ND & ND & ND & ND & ND & ND \\
\hline DWP-1-13 & 722 & 135 & 9.24 & 121 & 1.19 & .178 & .073 & ND & 3 & ND & ND & ND & ND \\
\hline DWP-128-1 & 568 & 110 & 6.5 & 103 & 1.81 & .86 & 1.43 & ND & 4 & ND & 2 & ND & ND \\
\hline DWP-1-9 & 762 & 115 & 9.37 & 106 & 1.19 & .122 & .039 & ND & ND & ND & ND & ND & ND \\
\hline DWP-4-10 & 763 & 134 & 14.6 & 137 & .475 & .93 & 1.67 & ND & 1 & ND & ND & ND & ND \\
\hline DWP-4-14 & 723 & 181 & 10.7 & 67.4 & 1.31 & .035 & .022 & ND & ND & ND & ND & ND & ND \\
\hline DWP-4-2 & -- & -- & -- & -- & -- & -- & -- & ND & ND & ND & ND & ND & ND \\
\hline DWP-4-4 & -- & -- & -- & -- & -- & -- & -- & ND & ND & ND & ND & ND & ND \\
\hline DWP-4-5 & 724 & 109 & 7.67 & 150 & 1.06 & .039 & .29 & ND & ND & ND & ND & ND & ND \\
\hline DWP-4-8 & 574 & 83.1 & 6.5 & 109 & 1.03 & .106 & .009 & ND & ND & ND & ND & ND & ND \\
\hline DWP-4-9 & 732 & 108 & 7.69 & 136 & .9 & .026 & .007 & ND & ND & ND & ND & ND & ND \\
\hline DWP-5-12 & 463 & 62.9 & 5.31 & 104 & .56 & 1.71 & .948 & ND & ND & ND & ND & ND & ND \\
\hline DWP-5-13 & 528 & 102 & 6.32 & 62.9 & 1.9 & .029 & .006 & 3 & 3 & ND & ND & ND & ND \\
\hline DWP-7-6 & -- & -- & -- & -- & -- & -- & -- & ND & ND & ND & ND & ND & ND \\
\hline DWP-BG-10 & 617 & 109 & 5.58 & 115 & 1.37 & .102 & .006 & ND & ND & ND & ND & ND & ND \\
\hline DWP-BG-4 & 604 & 92.2 & 5.64 & 109 & 1.3 & .11 & .009 & 98 & ND & ND & ND & ND & ND \\
\hline DWP-BG-4-3 & 697 & 113 & 11.6 & 128 & 1.86 & .019 & .005 & 43 & ND & ND & ND & ND & ND \\
\hline DWP-BG-4-6 & 584 & 66.3 & 5.49 & 144 & 1.25 & .061 & .002 & ND & ND & ND & ND & ND & ND \\
\hline DWP-BG-6 & 564 & 151 & 6.09 & 33 & 1.36 & .69 & .013 & ND & ND & ND & ND & ND & ND \\
\hline DWP-BG-7 & 717 & 136 & 7.82 & 119 & .99 & .049 & .001 & ND & ND & ND & ND & ND & ND \\
\hline DWP-BG-8 & 625 & 80.9 & 3.44 & 146 & .825 & .146 & .003 & ND & ND & ND & ND & ND & ND \\
\hline DWP-DBG-3 & 603 & 82.6 & 3.51 & 147 & .846 & .166 & .003 & ND & ND & ND & ND & ND & ND \\
\hline DWP-L1-5 & 426 & 46.5 & 3.6 & 117 & .74 & 3.55 & .36 & ND & ND & ND & ND & 7 & ND \\
\hline DWP-L2-1 & 502 & 117 & 6.1 & 85.8 & .9 & .25 & .05 & ND & 200 & ND & ND & ND & ND \\
\hline
\end{tabular}


Data from EnSafe/Allen \& Hoshall contract laboratory, September 1997-Continued

\begin{tabular}{|c|c|c|c|c|c|c|c|c|c|c|c|c|c|}
\hline $\begin{array}{c}\text { Well } \\
\text { number }\end{array}$ & $\begin{array}{l}\text { Dissolved } \\
\text { solids, } \\
\text { calculated } \\
(\mathrm{mg} / \mathrm{L})\end{array}$ & $\begin{array}{c}\text { Calcium } \\
\text { (mg/L) }\end{array}$ & $\begin{array}{c}\text { Magne- } \\
\text { sium } \\
\text { (mg/L) }\end{array}$ & $\begin{array}{c}\text { Sodium } \\
\text { (mg/L) }\end{array}$ & $\begin{array}{l}\text { Potas- } \\
\text { sium } \\
(\mathrm{mg} / \mathrm{L})\end{array}$ & $\begin{array}{l}\text { Iron } \\
\text { (mg/L) }\end{array}$ & $\begin{array}{c}\text { Manga- } \\
\text { nese } \\
\text { (mg/L) }\end{array}$ & $\begin{array}{c}\text { Tetrachlo- } \\
\text { roethene } \\
(\mu \mathrm{g} / \mathrm{L})\end{array}$ & $\begin{array}{c}\text { 1,1-Dichlo- } \\
\text { roethene } \\
(\mu \mathrm{g} / L)\end{array}$ & $\begin{array}{c}1,1,1- \\
\text { Trichlo- } \\
\text { roethane } \\
(\mu \mathrm{g} / \mathrm{L})\end{array}$ & $\begin{array}{c}\text { 1,1-Dichlo- } \\
\text { roethane } \\
(\mu \mathrm{g} / \mathrm{L})\end{array}$ & $\begin{array}{c}\text { Benzene } \\
(\mu \mathrm{g} / \mathrm{L})\end{array}$ & $\begin{array}{c}\text { Toluene } \\
(\mu \mathrm{g} / \mathrm{L})\end{array}$ \\
\hline DWP-L2-16 & 438 & 97.3 & 5.62 & 67.3 & 0.88 & 0.36 & 0.009 & ND & 54 & ND & 12 & ND & ND \\
\hline DWP-L2-4 & 345 & 87.6 & 4.5 & 36.2 & 1.08 & 5.18 & .14 & ND & ND & ND & ND & ND & ND \\
\hline DWP-L2-5 & -- & -- & -- & -- & -- & -- & -- & ND & ND & ND & ND & ND & ND \\
\hline DWP-L2-8 & 693 & 118 & 8.65 & 98 & 1.21 & .32 & .01 & ND & ND & ND & ND & ND & ND \\
\hline DWP-L2-DW1 & 774 & 3.15 & .67 & 167 & & .102 & .006 & ND & 3 & ND & ND & ND & ND \\
\hline DWP-L2-DW2 & 607 & 88.2 & 8.01 & 108 & 4.41 & 5.75 & .453 & ND & ND & ND & ND & ND & ND \\
\hline DWP-OFF-10 & 734 & 143 & 8.53 & 118 & 1.2 & .37 & .009 & 6 & ND & ND & ND & ND & ND \\
\hline DWP-OFF-11 & 805 & 156 & 8.73 & 127 & 1.42 & .31 & .008 & ND & ND & ND & ND & ND & ND \\
\hline DWP-OFF-12 & -- & 158 & 8.71 & 28.7 & 2.2 & .704 & .496 & ND & ND & ND & ND & ND & ND \\
\hline DWP-OFF-14 & -- & 161 & 9.4 & 39.4 & 3.2 & 7.21 & 2.36 & ND & ND & ND & ND & ND & ND \\
\hline DWP-OFF-5 & 1,001 & 138 & 13.7 & 200 & 1.88 & .322 & .03 & 170 & ND & ND & ND & ND & ND \\
\hline DWP-S1-10 & 551 & 112 & 5.78 & 81.9 & 1.73 & .19 & .085 & 1 & 77 & ND & 11 & ND & ND \\
\hline DWP-S1-11 & -- & -- & -- & -- & -- & -- & -- & ND & ND & ND & ND & ND & ND \\
\hline DWP-S1-17 & 384 & 81.2 & 7.4 & 54.5 & 1.2 & 3.28 & .77 & ND & ND & ND & ND & ND & ND \\
\hline DWP-S1-18 & 411 & 76.1 & 4.17 & 93 & .99 & .23 & .006 & 1 & 70 & ND & 27 & ND & ND \\
\hline DWP-S1-4 & & 120 & 7.43 & 75.1 & .68 & .18 & .15 & .9 & 270 & ND & 110 & ND & ND \\
\hline DWP-S1-5 & -- & -- & -- & -- & -- & -- & -- & ND & ND & ND & ND & ND & ND \\
\hline DWP-S1-7 & 598 & 119 & 7.2 & 103 & 1.07 & .11 & .006 & 8 & 1,100 & 18 & 60 & ND & ND \\
\hline DWP-S1-DW1 & -- & -- & -- & -- & -- & -- & -- & ND & ND & ND & ND & ND & ND \\
\hline DWP-S1-DW2 & -- & -- & -- & -- & -- & -- & -- & ND & ND & ND & ND & ND & ND \\
\hline DWP-S2-11 & 614 & 122 & 5.94 & 95.3 & .97 & .18 & .014 & ND & 5 & ND & 4 & 1 & ND \\
\hline DWP-S2-16 & 564 & 93.5 & 9.05 & 99.9 & 1.29 & 2.06 & 1.22 & ND & 12 & ND & ND & ND & ND \\
\hline DWP-S2-18 & 578 & 103 & 9.46 & 98.8 & 2.23 & 1.73 & .096 & ND & 2 & 2 & ND & ND & ND \\
\hline DWP-S2-2 & 624 & 91.6 & 6.64 & 136 & 2.18 & 1.77 & .81 & ND & 8 & ND & 25 & ND & ND \\
\hline DWP-S2-5 & 558 & 94.4 & 7.66 & 101 & 2.65 & 5.32 & 1.52 & ND & 4 & ND & ND & ND & ND \\
\hline DWP-S2-DW1 & 1,264 & 105 & 18 & 295 & 6.47 & 1.93 & .143 & ND & ND & ND & ND & ND & ND \\
\hline DWP-S2-DW2 & 603 & 87.5 & 10.3 & 97.2 & 3.77 & .375 & .269 & ND & ND & ND & ND & ND & ND \\
\hline DWP-S5-10 & 694 & 140 & 9.24 & 96.9 & 1.06 & .019 & .002 & ND & ND & ND & ND & ND & ND \\
\hline
\end{tabular}


Data collected by USGS and analyzed by Quanterra Laboratories, September 1997

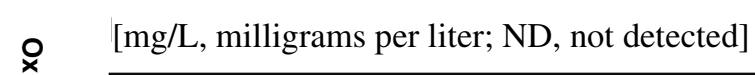

\begin{tabular}{|c|c|c|c|c|c|c|c|c|c|c|c|}
\hline Well number & $\begin{array}{c}\text { Alkalinity, } \\
\text { bicarbonate } \\
\left(\mathrm{mg} / \mathrm{L} \mathrm{HCO}_{3}\right)\end{array}$ & $\begin{array}{c}\text { Sulfate } \\
\left(\mathrm{mg} / \mathrm{L} \mathrm{SO}_{4}\right)\end{array}$ & $\begin{array}{l}\text { Chloride } \\
\text { (mg/L Cl) }\end{array}$ & $\begin{array}{l}\text { Fluoride } \\
\text { (mg/L F) }\end{array}$ & $\begin{array}{c}\text { Silica } \\
\left(\mathrm{mg} / \mathrm{L} \mathrm{SiO}_{2}\right)\end{array}$ & $\begin{array}{c}\text { Nitrate } \\
\text { nitrogen } \\
\left.(\mathrm{mg} / \mathrm{L} \mathrm{NO})_{3}\right)\end{array}$ & $\begin{array}{c}\text { Nitrate plus } \\
\text { nitrite nitrogen } \\
(\mathrm{mg} / \mathrm{L} \\
\left.\mathrm{NO}_{3}+\mathrm{NO}_{2}\right)\end{array}$ & $\begin{array}{c}\text { Ammonia } \\
\text { nitrogen } \\
\left(\mathrm{mg} / \mathrm{L} \mathrm{NH}_{4}\right)\end{array}$ & $\begin{array}{c}\text { Orthophosphate } \\
\text { phosphorus } \\
\left.\text { (mg/L } \mathrm{PO}_{4}\right)\end{array}$ & $\begin{array}{l}\text { Boron } \\
\text { (mg/L B) }\end{array}$ & $\begin{array}{c}\text { Total organic } \\
\text { carbon } \\
(\mathrm{mg} / \mathrm{L})\end{array}$ \\
\hline DWP-10-1 & 449 & 4.9 & 16.6 & ND & 12.2 & ND & ND & 1.1 & ND & 0.12 & 7.3 \\
\hline DWP-10-DW4 & 387 & 326 & 21.5 & ND & 17.8 & ND & ND & 1 & ND & .89 & ND \\
\hline DWP-1-13 & 491 & 146 & 42.4 & 1 & 21.6 & ND & ND & ND & ND & .35 & 1.3 \\
\hline DWP-128-1 & 318 & 104 & 61.9 & 1.3 & 19.7 & 1.2 & 1.4 & .47 & ND & .26 & 3.8 \\
\hline DWP-1-9 & 460 & 115 & 52.6 & 1.2 & 21.3 & ND & .39 & ND & ND & .27 & ND \\
\hline DWP-4-10 & 690 & 70.1 & 40.2 & ND & 19.1 & ND & ND & .23 & .42 & .56 & 2.4 \\
\hline DWP-4-14 & 519 & 124 & 55 & ND & 23.6 & ND & ND & .3 & .51 & .29 & ND \\
\hline DWP-4-2 & 546 & 141 & 18.7 & ND & 25.3 & 2.8 & 3.4 & ND & .16 & .27 & 2.4 \\
\hline DWP-4-4 & 478 & 86.5 & 39.1 & ND & 17.3 & ND & ND & 2.2 & ND & .3 & 1.6 \\
\hline DWP-4-5 & 554 & 120 & 34.8 & ND & 24.1 & 1.6 & 1.8 & ND & ND & .31 & ND \\
\hline DWP-4-8 & 472 & 92.3 & 24.5 & .58 & 21.1 & 1.1 & 1.3 & ND & .22 & .25 & ND \\
\hline DWP-4-9 & 581 & 135 & 29.9 & ND & 23.7 & ND & .46 & .21 & .14 & .29 & 2.5 \\
\hline DWP-5-12 & 433 & 5.9 & 42.6 & 1.7 & 22.1 & ND & ND & .11 & ND & .35 & 2.9 \\
\hline DWP-5-13 & 375 & 57.8 & 24.7 & 1.4 & 22.8 & ND & ND & ND & ND & .2 & ND \\
\hline DWP-7-6 & 500 & 67.7 & 28.4 & .83 & 24.6 & 1 & 1.1 & ND & ND & .26 & ND \\
\hline DWP-BG-10 & 522 & 69.5 & 30.2 & .65 & 24.8 & 2.3 & 2.4 & $\mathrm{ND}$ & ND & .3 & ND \\
\hline DWP-BG-4 & 410 & 133 & 34.9 & .97 & 22.6 & 2 & 2.4 & ND & .12 & .18 & ND \\
\hline DWP-BG-4-3 & 480 & 148 & 32.1 & .95 & 22.4 & 1.9 & 2.1 & $\mathrm{ND}$ & ND & .2 & ND \\
\hline DWP-BG-4-6 & 441 & 86.8 & 38.3 & 1.1 & 21.4 & 1.2 & 1.4 & ND & .056 & .19 & ND \\
\hline DWP-BG-6 & 427 & 102 & 31.5 & .64 & 24.6 & 2.6 & 2.7 & $\mathrm{ND}$ & ND & .1 & ND \\
\hline DWP-BG-7 & 538 & 105 & 53.4 & .65 & 26.2 & 1 & 1.4 & ND & .61 & .2 & ND \\
\hline DWP-BG-8 & 514 & 84.5 & 28.4 & 1.1 & 23.4 & 2.1 & 2.2 & ND & ND & .22 & ND \\
\hline DWP-DBG-3 & 455 & 55.6 & 64 & 1.1 & 21.4 & ND & ND & .17 & ND & .27 & 2.5 \\
\hline DWP-L1-5 & 395 & ND & 42.2 & 1.5 & 15 & ND & ND & 1.2 & ND & .26 & 5 \\
\hline DWP-L2-1 & 337 & 71.2 & 29.1 & .76 & 23.4 & 25 & 26.1 & ND & ND & .23 & ND \\
\hline
\end{tabular}


Data collected by USGS and analyzed by Quanterra Laboratories, September 1997-Continued

\begin{tabular}{|c|c|c|c|c|c|c|c|c|c|c|c|}
\hline Well number & $\begin{array}{c}\text { Alkalinity, } \\
\text { bicarbonate } \\
\left(\mathrm{mg} / \mathrm{L} \mathrm{HCO}_{3}\right)\end{array}$ & $\begin{array}{c}\text { Sulfate } \\
\left(\mathrm{mg} / \mathrm{L} \mathrm{SO}_{4}\right)\end{array}$ & $\begin{array}{l}\text { Chloride } \\
\text { (mg/L Cl) }\end{array}$ & $\begin{array}{l}\text { Fluoride } \\
\text { (mg/L F) }\end{array}$ & $\begin{array}{c}\text { Silica } \\
\left(\mathrm{mg} / \mathrm{L} \mathrm{SiO}_{2}\right)\end{array}$ & $\begin{array}{c}\text { Nitrate } \\
\text { nitrogen } \\
\left.(\mathrm{mg} / \mathrm{L} \mathrm{NO})_{3}\right)\end{array}$ & $\begin{array}{c}\begin{array}{c}\text { Nitrate plus } \\
\text { nitrite nitrogen } \\
(\mathrm{mg} / \mathrm{L} \\
\left.\mathrm{NO}_{3}+\mathrm{NO}_{2}\right)\end{array}\end{array}$ & $\begin{array}{c}\text { Ammonia } \\
\text { nitrogen } \\
\left(\mathrm{mg} / \mathrm{L} \mathrm{NH}_{4}\right)\end{array}$ & $\begin{array}{c}\text { Orthophosphate } \\
\text { phosphorus } \\
\left.\text { (mg/L } \mathrm{PO}_{4}\right)\end{array}$ & $\begin{array}{l}\text { Boron } \\
\text { (mg/L B) }\end{array}$ & $\begin{array}{c}\text { Total organic } \\
\text { carbon } \\
(\mathrm{mg} / \mathrm{L})\end{array}$ \\
\hline DWP-L2-16 & 271 & 75.4 & 33.7 & 0.82 & 22.3 & 14.8 & 15.6 & ND & ND & 0.18 & ND \\
\hline DWP-L2-4 & 218 & 42.7 & 37.3 & .79 & 20.9 & 3.2 & 3.5 & ND & ND & .18 & ND \\
\hline DWP-L2-5 & 386 & 108 & 59 & ND & 25.1 & 8.4 & 9.5 & ND & ND & .25 & ND \\
\hline DWP-L2-8 & 682 & 79.3 & 20.5 & 1.5 & 25.8 & ND & ND & .93 & ND & .37 & 2.9 \\
\hline DWP-L2-DW1 & 406 & 128 & 41.5 & ND & 27.6 & 3.9 & 4.2 & ND & ND & .21 & ND \\
\hline DWP-L2-DW2 & 497 & 60 & 54.2 & 2.5 & 29.8 & ND & ND & ND & ND & .31 & 11.9 \\
\hline DWP-OFF-10 & 528 & 107 & 66.6 & .68 & 25.2 & 2.8 & 3.1 & ND & ND & .19 & ND \\
\hline DWP-OFF-11 & 538 & 123 & 95.2 & ND & 24.4 & 1.5 & 1.8 & ND & .091 & .19 & 1 \\
\hline DWP-OFF-5 & 495 & 278 & 96.1 & ND & 25.8 & 2.3 & 2.7 & ND & .18 & .22 & ND \\
\hline DWP-S1-10 & 425 & 71.8 & 43.3 & ND & 21.5 & 2.1 & 2.5 & ND & ND & .22 & ND \\
\hline DWP-S1-11 & 422 & 88.7 & 21.3 & .65 & 21.9 & ND & .25 & ND & ND & .58 & ND \\
\hline DWP-S1-17 & 348 & 25.5 & 18.1 & 1.6 & 17.9 & ND & .12 & .87 & ND & .18 & 2.3 \\
\hline DWP-S1-18 & 271 & 54.8 & 22.9 & .83 & 23.2 & 2 & 2.4 & ND & ND & .22 & ND \\
\hline DWP-S1-4 & 372 & 62.9 & 33.8 & 1.3 & 25.5 & ND & ND & ND & ND & .2 & ND \\
\hline DWP-S1-5 & 398 & 59.8 & 35.1 & 1.4 & 23.2 & 1.7 & 2.1 & ND & ND & .21 & ND \\
\hline DWP-S1-7 & 442 & 85.5 & 35.1 & .75 & 26.2 & 1.5 & 1.9 & .5 & ND & .21 & 1.1 \\
\hline DWP-S1-DW1 & 247 & 55.7 & 27.7 & .89 & 21.9 & ND & ND & .89 & ND & .52 & 4.7 \\
\hline DWP-S1-DW2 & 420 & 61.6 & 19 & ND & 20.2 & ND & ND & .32 & ND & .6 & ND \\
\hline DWP-S2-11 & 488 & 75.8 & 45 & ND & 24.5 & ND & .35 & ND & ND & .22 & ND \\
\hline DWP-S2-16 & 494 & 60 & 30.4 & .64 & 19.1 & ND & ND & .42 & .12 & .21 & ND \\
\hline DWP-S2-18 & 520 & 59.2 & 21.3 & .83 & 22.3 & ND & .12 & .41 & .57 & .23 & ND \\
\hline DWP-S2-2 & 520 & 65 & 38.7 & .78 & 21 & ND & ND & .21 & .41 & .27 & ND \\
\hline DWP-S2-5 & 513 & 32.3 & 39.1 & .59 & 18 & ND & ND & 1.9 & .18 & .21 & 1.9 \\
\hline DWP-S2-DW1 & 389 & 594 & 32.3 & 1.8 & 16.5 & ND & ND & 1.4 & ND & 1.7 & 11.7 \\
\hline DWP-S2-DW2 & 293 & 220 & 21.2 & .69 & 15.4 & ND & ND & .37 & .083 & .42 & ND \\
\hline DWP-S5-10 & 494 & 130 & 45.4 & .65 & 24.4 & 1.6 & 1.8 & ND & .094 & .18 & ND \\
\hline
\end{tabular}


